\title{
II. Meşrutiyet Döneminde İslamcıların Milliyetçilik Tartışması : Babanzade Ahmet Naim Örneği
}

\section{Islamists' Discussion on Nationalism During the II. Constitutional Era Example of Babanzade Ahmet Naim}

Orhan Keskintaş ${ }^{\text {a,* }}$

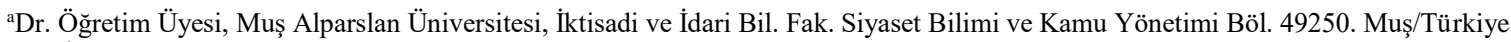
ORCID: 0000-0002-8210-2232

\section{MAKALE BILLGISİ}

Makale Geçmişi:

Başvuru tarihi: 31 Mayıs 2020

Düzeltme tarihi: 08 Ekim 2020

Kabul tarihi: 14 Ekim 2020

\section{Anahtar Kelimeler:}

İslamcilik

Milliyetçilik

Babanzade Ahmet Naim

ittihad-1 İslam

Osmanlicılik

\section{ARTICLE INFO}

\section{Article history:}

Received 31 May 2020

Received in revised form 08 October 2020

Accepted 14 October 2020

\section{Keywords:}

Islamism

Nationalism

Babanzade Ahmet Naim

İslamic Union

Ottomanism
ÖZ

II. Meşrutiyet, bugüne kadar devam eden birçok politik akımın partileştiği ve dergi çıkardığı bir dönemdir. Yapılan tartışmalar, yeni kurulan devletin temellerini de etkilemiștir. $\mathrm{Bu}$ dönmede İslamcılar, milliyetçi düşünceyi, ittihad-1 İslam'a ve Osmanlı Devleti'ne bir tehdit olarak algılamakta ve eleştirmektedir. Çalışma, bu bağlam içinde Ahmet Naim'in başlattığı İslam'da milliyetçilik tartışmasını analiz etmeyi amaçlamaktadır. Dinsel temellerle yürütülen tartışmanın taraflarından olan İslamcıların, bu tartışmada, kavramların tarihsel süreç içinde kazandığı yeni anlamları ve sosyolojiyi ihmal ettiği savunulmuştur. Çalışma, milliyetçi hareketlere yönelik İslamcı eleştirinin sınırlarını belirlemeye katkı sağlamayı ummaktadır

\section{Giriş}

II. Meşrutiyet döneminde İslamcılar ile milliyetçiler arasındaki tartışmayı konu alan bu çalışmanın ilk kısmında, tartışmanın tarihsel çerçevesinin belirlenmesi amacıyla üç tarzı siyaset analiz edilecektir. Üç tarzı siyasetten olan Osmanlıcılık, İslamcılık ve Türkçülük, siyasal akımlar olmakla birlikte Osmanlı Devleti'nin Batı ile temasinı ve devlet politikasının art arda gelen uygulanma momentlerini de ifade etmektedir. Halef ve selef ilişkisini taşıyan akımlar, diğerini eleştirirken yeni içerikler de kazanmıştır. İslamcıların Yeni Osmanlıcılık düşüncesine yakın olmaları, Türkçülerin ilk dönemde İslamcı dergilerde yazmaları bu üç düşünceyi birlikte ve iç içe değerlendirmeyi zorunlu kılmaktadır. $\mathrm{Bu}$ tarihsel çerçevenin değerlendirilmesinden sonra ittihad-1 İslam ile Osmanlıcılık akımı arasındaki örtüşen kısımlar analiz edilecektir. Bu analiz sonucu İslamcılığın ittihad-ı İslam taraftarlığının aynı zamanda Osmanlı Devleti savunusu olduğu ileri sürülecektir. Sonraki bölümlerde ise Babanzade Ahmet Naim'in milliyetçilik eleştirisi ve Ağaoğlu ve Gökalp’ın bu eleştiriye verdiği cevaplar değerlendirilecektir.

* Sorumlu yazar/Corresponding author
e-posta: o.keskintas@ alparslan.edu.tr 
Babanzade Ahmet Naim (1872-1934) Bağdat'ta doğdu. Galatasaray Lisesi ve Mülkiye Mektebi'nden mezun oldu. Kendi döneminin birçok Osmanlı aydını gibi Abdulhamid, II. Meşruiyet ve Cumhuriyet gibi üç dönemi birden yaşadı. Osmanlı münevveri ve bir İslamcı olarak Ahmet Naim'in bu dönemde fikirlerine bütünlük ve anlam veren temel endişesi, ittihad-1 İslam kaygısıdır.

\section{Tartışmanın Tarihsel Çerçevesinin Oluşumu}

Üç tarz-1 siyaset, devleti kurtarmayı amaçlayan fikir hareketleridir. Yusuf Akçura (1976: 27) üç tarz-1 siyasetin tamamının temel amacının Osmanlı menfaatine çalışmak olduğunu savunur. Bu durumda sorun bu tarz-1 siyasetin hangisinin "kabil-i tatbik" olduğu ile ilgilidir. Çetinsaya'ya göre (2009: 264) uhuvvet-i siyasiye yaratarak Osmanlı Devleti'nin kurtulacağına dair kanaati herkes paylaşmaktadır. Tartışma "uhuvvet-i siyasiyenin nokta-i istinadı meselesi" üzerinedir. Karar verilemeyen uhuvvet-i siyasiyenin hangi görüşe, neye dayanması gerektiğidir. Osmanlıcılık, milliyetçilik ve İslamcılık tartışması teolojik ve düşünsel olmaktan çok uhuvvet-i siyasiyenin nereye dayanacağı üzerine politik bir tartışmadır.

\subsection{Osmanlıcilik}

Osmanlı Devleti, 18. yüzyıldan itibaren Batı karşısında güçlü olma, sınırlarını koruma adına askeri, ekonomik, siyasal ve idari birçok tedbir aldı. 1774 yılında yapılan Küçük Kaynarca anlaşması sonucu Rusya'nın, Osmanlı tebaası gayrimüslimleri koruma hakk1 elde etmesi, gayrimüslimlerin statü ve durumlarının dış politikanın konusu olmasıyla sonuçlandı. Rum ayaklanması ve bu ayaklanmadan dolayı Rum Patriği’nin asılması (21 Nisan 1821) geçmişe ait milletler sisteminin kompartıman şeklinde toplumsal yapıyı kontrol edemediğinin önemli bir işaretiydi. Özellikle, Rum ve Ermeni gençlerin yurtdışında okuması sonucu milliyetçi hareketlerin Osmanlıda yayılması, idari ve siyasi düzenlemelerin dışında ideolojik tedbirlerin de içerde alınmasını zorunlu kıldı. Osmanlıcılık milliyetçilik çağı olarak kabul edilen bu dönemde, yeni bir vatandaşlık tanımı ve tesisi için gündeme geldi.

Fransız Devrimi'nin 'özgürlük, eşitlik, kardeşlik' ilkesi Osmanlıda 'özgürlük, eşitlik, ulusallık' biçimini almıştır (Arai, 2008: 15). Fransız Devrimi'nin ulusçuluk düşüncesine karşı koymak için Osmanlı Devleti'nin bulduğu ilk yanıt Osmanlılık kimliğiydi. Osmanlılık düşüncesi, kendini oluşturabilmesi için vatandaşlık temelinde inşa edilen eşitlik kavramına ihtiyaç vardı. S. A. Somel'e göre (2009: 88) Osmanlı döneminde Osmanlıcılık düşüncesi dört aşama halinde gelişti:

i. İlk aşama 1830-1875 tarihleri arasında Babı Âli’nin otoriter merkeziyetçi siyasetinin sonucu oluşan,

ii. 1868-78 tarihleri arasında Yeni Osmanlı muhalefeti ve meşrutiyetçi pragmatizm etkisi altında gelişen,

iii. II. Abdulhamid'e karşı Jön Türk muhalefeti tarafindan temsil edilen,

iv. II. Meşrutiyet döneminde görülen Osmanlıcılık hareketidir.

Birincisi, devlet merkezli ve Kanun-i Esasi'nin Osmanlı tanımında ifade edilen devlet politikasıdır. Bu dönemde, Osmanlıcılık merkezileşen devletin ideolojik bir aracı olmanın yanında, Mithat Paşa ve Namık Kemal'de açıkça görüleceği gibi, belli coğrafyaya karşı duyulan vatanseverlik hissi olarak kendini göstermektedir. Namık Kemal'de "Osmanlı ümmeti," kavramı, farklı dil ve dinsel çeşitliliğe sahip olan Osmanlı coğrafyasında yaşayan insanların birliğine yönelik bir içeriğe sahiptir. İkincisi ise Kanun-i Esasi'nin askıya alınmasından sonra Jön Türklerin ideolojik ve muhalif düşüncelerinde kendini gösteren bir Osmanlıcı akımıdır. Osmanlıcılık, 1876 yılında ilan edilen Kanun-1 Esasi'nin 8. maddesinde “Devlet-i Osmaniye tabiiyetinde bulunan efradin cümlesine herhangi din ve mezhebden olur ise olsun bila istisna Osmanl tabir olunur." şeklinde tanımlanmıştır. 11. maddesi, Osmanlı Devleti'nin dini İslam olduğunu ifade eder. 68. maddesi ise mebus olarak seçilmek için Osmanlı vatandaşı olma ve Türkçe bilmeyi şart koşmaktadır. II. Meşrutiyet döneminde kurulan Osmanlı Demokrat Fırkası, Osmanlı Ahrar Fırkası, Hürriyet ve İtilaf Fırkası gibi birçok parti kendi programlarında Osmanlıcılık düşüncesini savunmuştur. Bu partiler ayrıca programlarında, yerel yönetim birimlerinin güçlendirilmesini savunmuştur. Ahrar Fırkası hariç, mezkûr partiler, parti programlarında yerel dillerde eğitim yapılmasını savunan birçok maddeye de yer vermiştir (Somel, 2009: 92, 110-1).

Çetinsaya, (2009: 265-6) Osmanlıcılık fikrinin birbirini tamamlayan üç farklı teklif içerdiğini savunur:

i. Tanzimat ve Islahat Fermanı ile talep edilen hukuki eşitliktir.

ii. Müslümanların imparatorluk içinde durumlarının iyileştirilmesidir. 1860'lardan sonra Osmanlı Devleti, kaynaklarının önemli bir kısmını gayrimüslimleri devlete bağlamak amacıyla onların yaşadıkları yere tahsis etmişti. Yetmezmiş gibi Cevdet ve Mithat Paşa gibi başarılı yöneticileri de Balkanlarda görevlendirdi. 1860'ların sonu ve 70'lerin başında Balkanlar'daki ayaklanmalar bütün bunlara rağmen devam etti. Bunun üzerine Namık Kemal'in de içinde bulunduğu yeni Osmanlıcı akım Müslüman ahalinin hukuken, idari ve ekonomik olarak ihmal edildiğini savundu. Eşitlik düşüncesinin Müslümanların aleyhine sonuçlandığını ileri sürmeye başladı.

iii. Gayrimüslimlerin ayaklanmalarına son vermek amacıyla meşruti yönetimin ilan edilmesi gerekliliğidir. $\mathrm{Bu}$ teklifle, meşruti rejime geçildiğinde, anayasal bir düzene kavuşulacağı dolayısıyla parlamento ve seçimler aracılığıyla siyasal eşitlik sağlanılacağ düşünüldü. Batıdaki birçok kurum bu yeni anayasal rejim aracılığgyla Osmanlı Devleti'ne taşınacağından gayrimüslimlerin şikâyetinin ortadan kalkacağına inanıld1.

Osmanlıcılık düşüncesinin temel problemi, vatandaşlık temeline dayanan Osmanlı kimliğinin bütün tebaa tarafindan kabul edilecek siyasi kardeşliği yaratmanın (uhuvvet-i siyasiye) nasıllığının belirsizliğiyle ilgilidir. Yeni milletler çağında vatandaşlık, soy ve dile dayalı olarak inşa ediliyordu. Osmanlı vatandaş kimliği, soy ve dilin dışında ABD'de olduğu gibi coğrafya ve siyasal bağ ile ilişkili kurmak durumundaydı. Ancak, tekno-askeri ve ekonomik gücü olmayan bir devletin dilsel ve dinsel farklılı̆̆ı aşabilmesinin maddi koşulları yoktu. Ayrıca, Arnavut ayaklanmasında olduğu gibi dinsel birliktelik siyasal bağın inşası için yeterli değildi. 


\section{2. İslamc1lik}

Babıâli'nin hukuki eşitlik, kaynakların gayrimüslimlerin lehine dağıtılması gibi politikalarına tepki olarak İslamcılığın geliştiği savunulur. Çetinsaya'ya (2009: 266) göre İttihad-1 İslam, Islahat Fermanı'na yönelik eleştiriler ve İslam dünyasının sömürgeleştirilmesi neticesinde, birçok muhacirin hilafet merkezine sığınması ve Osmanlıdan yardım beklentisi sonucu gelişen bir akımdır. Nitekim II. Meşrutiyet'ten sonra çıkan Sırâtımüstakîm ve Sebîlürreşâd dergileri incelendiğinde, sayfalarında, Rusya, Çin ve Afrika'da yaşayan Müslümanlarla ilgili düzenli haberlerin yer aldığı görülür. $\mathrm{Bu}$ haberlerde İstanbul, Müslümanların son umut yeri olarak takdim edilir.

Çetinsaya (2009: 267) ve Türköne’ye (1991: 231) göre ittihad-1 İslam, ilk olarak Osmanlı Devleti'nin öncülüğünde Müslümanların siyasi, fikri birlikteliği anlamında kullanılır. İttihad-1 İslam'ın anlamı Müslümanların yaşadıkları yerlerin siyasal birliğini içermektedir. İttihad-1 Slav ve ittihad-1 Cermen gibi düşüncelerden etkilenilmiştir. Ahmet Mithat, bu anlamda ittihad1, Rusya, İngiltere ve Fransa'yı karşıya almak olduğunu düşündüğünden muzır görürdü. Çetinsaya'ya göre ikinci kullanımı ise daha dar anlamda Osmanlı sınırları içinde yaşayan Müslümanları merkezi devlete bağlı kılmak amacı gütmektedir. Fakat gayrimüslimlerin sayısının çok olduğu bu dönemde ittihad-1 İslam düşüncesi, Osmanlıcılık düşüncesi ile çelişmektedir. Bunu bilen Namık Kemal “... dünyada İslam'ın ittihadı ve memalik-i Osmaniye'de akvamın imtizacı lazımdır ..." diyerek iki fikrin iki farklı mekânda savunulmasının uygun olduğunu düşünür. Namık Kemal'in savunduğu İttihad-1 İslam, “efkar- İslam'ın efkar-1 medeniyetle ittihadı"dır. Namık Kemal, (1997: 86-88) ittihadı İslam'ı savunduğu 1872 yılındaki makalesinde:

"Devleti Aliye'nin zuhurundan beri birtakım eazımın efkarını işgal eden ittihad-i İslam şimdi maksad-i umumiden olduğunu görüyoruz. Maksat bir kere hâsıl olursa iki yüz milyon kadar nüfus daderane ve yekvücudane birbirinin terbiye-i efkâr ve muhafaza-i menafiine çalışacaklarından Asya için ne revnaklı bir devr-i saadet zuhura geleceği tarife muhtaç değildir. Mesail-i malumedendir ki, kuvvetin tezayüdü teavünün tezayüdüyle hasıl olur."

Namık Kemal, yardımlaşma ile birlikte kuvvetin de artacağını düşünür. İttihadı da bütün bir varlığın intizamını sağlayan unsur olarak değerlendirir. Medeniyet ve toplulukları fabrikaya benzeten Namık Kemal, (1997: 8687) İslam medeniyetinin ileri seviyesini koruyamamasını tefrikaya bağlar. Osmanlı'nın diğer İslam ülkelerine göre daha ileride olduğunu vurgulayan Namık Kemal, diğer Müslümanları hilafetin merkezine bağladığımızda, "saltanat-i Osmaniye kesret-i askerde Avrupa'nın en büyük devletleriyle yarlşabilecek bir dereceye vasıl olur ve o suret ise şan ve ikbalimizin teyidine ve hal ve istikbalimizin teminine pek büyük hizmet eder." demektedir. Bunu söylemesine rağmen, ittihad-1 İslam'ın siyaset ve mezhep davasından vazgeçilmesi ile mümkün olacağını düşünen Namık Kemal, bu ittihad-1 İslam'ın nerede geçerli olacağını da açıklar: "Demek ki ehl-i Íslam suret-i ittihadını politika ağrazında veya mezhep mücadelelerinde değil, vaiz önlerinde, kitap sahifelerinde aramaya muhtaçtır." (Namık Kemal, 1997: 88).

H. K. Sevil, (2005:202) haklı olarak Yeni Osmanlıların savunduğu İslamcılık ile II. Meşrutiyet İslamcılığını ayırmaktadır. Ona göre Yeni Osmanlıcılar İslamcılığı, ideolojik bir süreç değil, kültürel bir olgu olarak değerlendirmektedir. II. Meşrutiyet'ten sonra İslamcılık, artık ideolojik temelleri olan, kitleleri harekete geçirme amacı taşıyan düşünce hareketidir. Bu dönemde, din artık modern bir ideoloji olarak algılanıp yorumlanmaktadır. Avrupa sömürgesi ve saldırıları karşısında, dinin, İslam dünyasını savunan "dinsel milliyetçi”" bir araç olduğu düşünülür. Panislamizm "proto nationalism" niteliği kazanarak geleneksel İslam'la modern milliyetçilik arasında bir geçişi temsil etmektedir. Gökalp de (2010: 41) Türkçülerin kendilerini İslam milliyetçilerinden ayırdığını söylerken dinin milliyetçi bir örgütlenme riskini barındırdığını ima etmiştir.

İslamcıların bu dönemde temel sorunu tefrikadır. Akif, İslam dünyasının en temel sorunu ve sömürgeleştirilmesine zemin sağlayanın tefrika olduğu savunur. Akif (2017: 375-376) Sebîlürreşâd'ın 6 Şubat 1913 tarihli yazısında şunları yazar:

“Avrupalılar zabt etmeyi kararlaştırdıkları memleketin ahalisi arasına evvelâ tefrika sokarlar, senelerce milleti birbiriyle boğuştururlar. Sersem ahalî bu sûretle yorgun düştükten sonra gelip çullanırlar. Bugün de işte bize karşı aynı siyâset kullanıldı. Zaten her yerdeki siyâsetleri budur. Müslüman olanlar iyi bilmelidirler ki: Bu tefrika, bu kavmiyet çıkmaz yoldur... Ey cemâat-i müslimîn! Artık gözünüzü açınız, aklınızı başınıza toplayınız; zîrâ taht-1 saltanat gicırdıyor! Böyle gidersek -el iyâzü billâh- o da devrilecek. Eğer Rusya'daki müslümanlar henüz dinlerini muhâfaza ediyorlarsa; eğer Fransızların taht-1 idâresindeki dindaşlarımız hâlâ tanassur etmemişlerse; eğer İngiltere, Hintli kardeşlerimize şimdilik ses çıkarmıyorsa... İyi biliniz ki, hep çürük çarık yine bu hükümet sâyesindedir. Maâzallâh bu giderse hepsinin gittiği gündür. Biz bu saltanatı muhâfaza edemiyorsak düşünmeliyiz ki bizim yüzümüzden o biçâreler de mahv olacaklar. Onların bütün nazarları, bütün ümidleri buraya ma'tûf idi. Hep bizden bir hayır bekliyorlardı... Bîçârelerin tâbi' oldukları ecnebi hükümetleri, kendilerine karşı, hep Osmanlı piyasasına bakarak muâmelede bulunuyorlar."

Akif, ittihat kavramı aracılığıyla Osmanlı Devleti'ne tarihsel görev yüklemektedir. Osmanlı Devleti'nin bütün Müslümanların ümidi olduğu, bu “çürük çarık" hükümetin Müslüman bölgelerde sömürgecilerin politikalarını yürütürken dikkate alındığını söylemektedir. Görüldüğü gibi, Akif açısından, İslam ve bunun dünyada savunucu ve ümidi olan Osmanlı Devleti'nin varlığı iç içe geçmiştir.

İslamcılar için temel sorun, birliği sağlamaktır. Birliğin sağlanması kuvvetin elde edilmesi şeklinde anlaşılmalıdır. Tefrika etik dışı bir tabir olmakla birlikte zayıflığı da içerir. İttihad bu açıdan İslam dünyasının karşı koyma kuvveti anlamına gelmektedir. İslamcılar ittihadı, İslami bir inanç içinde ararken onların İslamcı düşüncelerinin siyasal içeriğini de Kanun-i Esasi belirler. Kanun-i Esasi bilindiği üzere Osmanlıcılık düşüncesinin temel metnidir. 
Akif'in Osmanlı Devleti'nin çökmesi karşında bütün Müslümanların kaybedeceğine dair düşüncesi, ittihad-1 İslam'ın siyasal projesini de belirtir. Kara'ya (2009: 253) göre İslamcılık, Osmanlıcılık hareketinin dinsel bir dil kullanan devamı ve biçimidir.

\subsection{Türkçülük}

Babanzade Ahmet Naim, Ali Paşa'nın öldüğü yıl (1872) dünyaya gelmişti. Ahmet Naim'in mezunu olduğu Mülkiye, 1880'lerin başında Abdulhamid'e rağmen fikir merkezi haline dönüşmüştü. Devrin birçok tartışması örneğin dilde sadeleşme, edebiyat tartışmaları bu okulda da devam etmektedir. Yüzeyde edebi tartışma gibi görülse de, gerçekte eski ile yeninin bir tartışmasıydı. 1880'li yıllarda dil sorunu tartışmaları Abdulhamid döneminde siyasal sorunların tartışılmasına bir zemin hazırlamaktadır (Mardin, 2010: 50-52). Dil sorunu etrafinda yapilan tartışmalar siyasal alanda kişilerin hangi tutum takınacağının da habercisiydi. Dil ve milliyet arasındaki sıkı ilişki Osmanlı modernleşmesinde dilde sadeleşme yoluyla seküler bir ilişskiye de dönüşmektedir. Mardin'e göre Jön Türkler zamanında ilk emareleri görülen Türkçülük hareketi 1880'lerde lengüistik Türkçülük halinde görülmüştür. Türkçülük, Şemsettin Sami'nin eserlerinde bir lisaniyat sorunuyla ilgilidir. 1893 tarihinde İkdam Gazetesinin 'Türk gazetesidir' başlığı altında çıkması Türkçülüğün kültürel bir hareket olarak gelişeceğinin ilk işaretiydi (Mardin, 2010: 65).

Üç Tarz-1 Siyaset'in yazarı Akçura, (1976: 23) “Irk üzerine müstenid bir Türk siyasi milliyeti husule getirmek fikri pek yenidir. Gerek şimdiye kadar Osmanlı Devleti'nde gerekse gelip geçen diğer Türk devletlerinin hiçbirisinde bu fikrin mevcut olduğunu zannetmiyorum." demektedir. Anlaşılan, Türk milliyetçiliğinin geç gelişmesi ve İslamcılarla girdiği tartışmalar sonucunda düşünsel pozisyonunu belirlemiştir. Ahmet Naim (2018: 116) Türk milliyetçilerinin, "kabahat bizde değil, ilk başlayanlarda" sözlerini nakletmektedir. Diğer milliyetçi hareketlerden sonra Türkçü hareketin ortaya çıkması, kendileri açısından düşüncelerine bir meşruluk kazandırmaktadır. Türk milliyetçiliğinin gecikmesinin temel etkeni olarak İslam'ın, Türklügüü unutulmasına neden olduğu ileri sürülmüştür. Ayrıca, Osmanlı Devleti'nin millet-i hâkimi olan Türklerin, kendi ulusal kimliklerine açıktan sahip çıkmamaları bu gecikmeye neden olarak gösterilmektedir (Akçam, 2002: 54). Bu dönemde Türk milliyetçiliğinin gelişmesi birden fazla etkinin birleşmesinin sonucudur:

i. 19.yüzy1lda tarih, özellikle arkeolojinin gelişmesi,

ii. Oryantalistlerin Türklerle ilgili çalışmaları,

iii. Osmanlı Devleti'nin Orta Asya Türkleri ile siyasal ilişkilerinin geliştirilmesi,

iv. Savaşların etkisi ile Anadolu'nun bir göç yerine dönüşmesi,

v. Ticaretin gayrimüslimlerin elinde olması,

vi. Osmanlıcılık düşüncesinin uygulanamaz olması, gibi faktörler Türk milliyetçiliğinin gelişmesine neden olmuştur (Kushner, 2009: 24-36 ).

II. Meşrutiyet döneminde İslamcılar ile Türkçüler arasında gri alanların varlığı birçok kimsenin önce İslamcı sonra Türkçü olarak ifade edilmesine neden olmaktadır. Örneğin Ziya Gökalp (2010: 40, 42, 41) Türklerin ittihadı gerçekleşirse İslam'ın birliğinin ve Osmanlılı̆̆ın bütünlüğünün daha emin bir vaziyete gireceğini düşünür. Türkçülerin hiçbir zaman İslam ümmetçiliğine aykırı bir his beslemediğini, dolayısıyla suçlamanın yersizliğini ileri sürmüştür.

“Türkçülerin gayesi muasır bir İslam Türklüğüdür. Türkçülerin millet ülküleri Türklükse, ümmet ülküsü de İslamlıktır. Bence Türkçülerin ayrıca bir ümmet programları da olmalı ve başlıca esasları da şunlar olmalıdır... Arap harflerini değiştirmemek, Terimleri bütün İslam âleminde ortak k1lmak, ortak terbiye, müftü teşkilatları arasında daimi bağ kurulması, Hilal'in mukaddesliğini korumak... Bu esaslardan anlaşılıyor ki, Türkçülük aynı zamanda İslamcılıktır. Yalnız Türkçüler İslam ümmetçisi olmak suretiyle kendilerini İslam milliyetçilerinden ayırt ederler."

Bu üç akım Kara’ya göre (2018:194) Osmanlı Devleti'nin son yıllarına hatta Milli Mücadele'nin sonuna kadar iç içe var olmaya devam etmiştir. Çünkü gayrimüslim ve gayrı Türk tebaa hep olagelmiştir. Cumhuriyet devri de bu mirasın bütün tecrübelerini, netleşmiş yahut kompleks taraflarıyla devralacak ve kendi şartlarında sürdürecektir.

\section{3. İttihad-ı İslami ve Osmanlıcılık Arasındaki İlişki}

Yusuf Akçura 1904 yılında 'Üç Tarz-i Siyaset'i yazdıktan sonra cevap olarak aynı gazetede Kemal Ali'nin 'Cevabımız' adlı bir yazısı yayınlandı. Bu yazıda üç tarzı siyasetin birbirinden tefrik edilemeyeceğini, ittihad-1 İslam, ittihad-1 Osmani ve Türkçülük gibi akımların bir çok yanlarıyla birbirlerini içerdiğini, Osmanlı Devleti'ni yöneten kimselerin, böyle ham hayallere sahip olmadığını savundu. Ona göre “Türkü İslam'dan, İslami Türk'ten, Türk ve Íslam' $\imath$ Osmanlılıktan, Osmanlılılığ ${ }^{\prime}$ Türk ve İslam'dan ayırmak tekliği üçe bölmek, olamaz." (Kemal Ali, 1976: 37-44). Bu tartışmadan çok önce Mizan ve Saadet adlı iki önemli derginin 1887 yılında yaptıkları Müslüman, Osmanlı ve Türk üzerine tartışmaları da bu konuda önemlidir. Mizan dergisi, bu üç kimliğin de birbiriyle kopmaz bağlarının olduğunu savunmaktadır (Kushner, 2009: 59). Osmanlıcılık ile İslamcılık arasındaki ayrımı belirsiz kılan gri alanların varlığına en önemli örnek Namık Kemal'dir.

İslamcıların Kanun-1 Esasi’ye bakışları onların Osmanlıcılık fikirleriyle yakınlıklarını anlamamızı sağlar. Hatırlayım, Kanun-1 Esasi Osmanlıcı hareketin temel amaçlarından biriydi. Kara'nın (2009: 259) aktardığına göre, İslamcılar, Kanunu-1 Esasi'yi şöyle değerlendirmektedir:

i. "Kanun-1 Esasi şeriatin fezleksidir.”, "Kanun-1 Esasi ki kanun-1 ilahi demektir.” (Manastırlı İsmail Hakk1),

ii. "Şeriat-1 mutahhara-yı İslamiyenin müstelzim bulunduğu Kanun-1 Esasi” (İttahad-1 Muhammedi Cemiyeti),

iii. "Kur'anın bazı ahkamını beyandan başka bir şey olmayan Kanun-1 Esasimiz”, (Musa Kazım)

iv. "Ahkam-1 şeriyemizn şerh ve tafsili olan Kanun-1 Esasimiz", (Elmalılı Hamdi Yazır),

v. "Kanun-1 Esasi şeriata temessükün bir sened-1 kavimi[dir]." (Cemiyet-i İlmiye-i İslamiye). 
Ahmet Naim, (2018: 343) II. Meşrutiyet'le oluşacak hürriyeti, bütün olumsuzluklara rağmen, geleceğe umutla bakmanın nedeni olarak görmektedir. "Bir ay oluyor ki bina-yı mehîb-i istibdad yıkıldı. Kanun-ı Esasî ilan edildi. Hürriyetin hatr $u$ hayale gelmeyen envâ'-ı tecelliyâtı arz-l dîdâr-l hürriyet etti... Müstakbeli ümitlerle, nâzenin hayallerle besliyor... Hali, seyrine doyulmaz bir sahne-i behiştî gibi gösteriyor. Müstakbeli ümitlerle, nâzenin hayallerle besliyor."

Said Nursi'nin meşrutiyet hakkında sözleri ise daha ateşlidir. Ona göre, meşrutiyet, "onların işleri kendi aralarında şura iledir." ayetinin tecellisi ve hâkimiyet-i millettir.

"O vucud-u nuraninin kuvvete bedel hayatı hakdir. Kalbi marifettir. Lisanı muhabbettir. Aklı kanundur, şahıs değil. Umum akvamın sebeb-i saddetidir. ..Insanı hayvanlıktan kurtarır. Siz de tam insan olunuz...bizim devleti ömr-ü ebediye mazhar eder. Milletin bekası ile ibka eder... Herkesi bir padişah hükmüne getiriyor. Siz de hürriyetperverlikle padişah olmağa gayret ediniz... Zira meşveret perdeyi att1, milliyet göründü, harekete geldi... Meşrutiyet, hâkimiyet-i millettir.” (Said Nursi, 2004: 83,94)

1910 yılında yayın hayatına başlayan Genç Kalemler dergisinde Osmanlılık ve Türklük isimlerinin birbirinin yerine kullanılması hem Genç Kalemler'in hem de Osmanlı Türk milliyetçilerinin belirleyici niteliklerindendi (Arai, 2008: 74). II. Meşrutiyet döneminde, iki düşünce taraftarı da ittihad-1 anasırı savunma konusunda müttefiktirler. Manastırlı İsmail Hakkı Efendi, uhuvvet-i İslamiye yanında, bir de uhuvvet-i vataniye vardır, diyerek uhuvveti taksim etmektedir. Bunların birbirlerine karşı olmadıklarını söylemektedir (Tunaya, 2003: 76). Hüseyinzade Ali Bey gibi birçok Türk milliyetçisini etkileyen birinin Osmanlı İmparatorluğu ve Osmanlıcanın önderliğinde bütün Türklerin manevi bir yapı kurmalarını önermesi (Kushner, 2009: 34) üç tarz-1 siyasetin Ali Kemal'in dediği gibi Osmanlı Devleti'nde iç içe geçmiş düşünceler olması ile mümkündür. $\mathrm{Bu}$ nedenle Ahmet Naim ve diğer İslamcıların milliyetçiliği eleştirmelerinde Osmanlılık müntesipliği de önemlidir.

Kanun-1 Esasi'nin tekrar yürürlüğe girmesinden sonra İslamcı neşriyatta, İslamcılık ile Osmanlıcılık arasında sınırların belirsizleştiğini de görmek mümkündür. Çünkü "din ü devlet" "mülk ü millet" düşüncesine bir de Fransız Devrimi'nin de etkisi ile oluşan "uhuvvet" düşüncesi eklenince İslamcılar, Osmanlı Devleti'ni İslami açıdan temellendirmekte zorlanmadılar. Manastırlı İsmail Hakkı Efendi (2012: 27),

“Onun için biz de İngiltere'nin, Fransa'nın insâniyetine, ahlâkına muvâfık, hakkāniyetle olan şu gayretini medh u senâ edelim. Dünya ciheti başka, âhiret ciheti başka; nefse âid cihet başka, dîn ciheti başka. Sonra içimizde bulunan Yahûdîler, Ermeniler var. Mâdem ki birlikte yaşıyorlar, hep bir vatan kardeşiyiz. Uhuvvet mertebe mertebedir. Uhuvvet-i dîniyye olur, uhuvvet-i cinsiyye olur, uhuvvet-i vataniyye olur. Mâdem ki bir toprakda, bir vatanda yaşarız, elbet vatandaşlarımızdır."
Manastırlı tarafindan, uhuvvet kavramı, din, vatan, Osmanlı gibi birçok kavramla irtibatlı, tamlayan olarak kullanılmaktadır. Dünya ve ahiret açısından da uhuvveti tasnif eder, böylece Osmanlı Devleti'nin ihtiyaç duyduğu gayri Müslimleri de içine alan kardeşlik vatan üzerinden tesis edilir. $\mathrm{Bu}$ durumda Osmanlı içinde yaşayan Müslümanların ittihad-1 İslam'1, ittihad-1 anasırın temellerini de teşkil etmektedir. İkisi birbirini tamamlayan öğelere dönüşmektedir.

Said Nursi (2004: 107-116) II. Meşrutiyet'i savunmak ve Kürtlerin bazı tereddütlerini gidermek amacıyla 1911 yılında doğu illerini ziyaret eder. $\mathrm{Bu}$ ziyaretinde, geleneksel Müslümanların, gayri Müslimlerle eşit olma, zimmî hukuku, Yahudi ve Hıristiyanlarla dost olma, kaymakam ve yöneticilerin gayri Müslimlerden atanması gibi birçok sorulara cevap verir. Nursi, ittihad-1 Osmani'nin İslam açısından sorun olmadığını açıklamaya çalışır. Verdiği cevapların arkasında, ittihad, terakki ve eşitlik gibi temel düşüncelerin İslam ve Osmanlı için gerekliliği yer almaktadır.

Ancak, ittihad-ı İslam'ın Batı ve Rusya'yı karşıya almak olduğunu bilen İslamcılar daha dikkatli ve pragmatik davranmıştır. 19 Şubat 1914 tarihli Sebîlürreşâd'ta Sirâcü'l-Ahbâr'dan alıntılanan "Uhuvvet-i İslâmıyye 1300 Sene Evvel Teessüs Etmiş Fitrî Bır Râbıtadır” yazıda, Rusya'nın tanınmış bir gazetesinin Avrupa kamuoyunda Osmanlıy1, zor duruma sokmak için Hindistan'da ittihad-1 İslam için çalıştığı konusunda ithamlarının olduğunu söylemektedir. Rus gazetesinin ithamının batıl olduğunu söyleyen gazete, Müslümanların, 1300 yıldır birbirleriyle kardeş olduğunu, sevinçlerinden mesrur, kederlerinden mükedder olduğunu ileri sürer. Enver Paşa'ya olan muhabbetlerinin geçmişte benzerini Osman Gazi Paşa'ya da duyduklarını, Hindistan'da halkın ellerinde Balkan mezalimine ait dolaşan fotoğrafların Osmanlı tarafından değil, Avrupalı basın tarafindan yayınlanmış olduğunu söyler. Son olarak da gazete "Rus gazetesi bilmelidir ki bu hissiyât, politika ve siyâset âlemine merbût değildir. Belki dînimizin bize bahşettiği terbiye-i asliyenin semerât- meşrûa ve netâyic-i tabîiyyesinden başka bir şey değildir." diyerek, politik alan ile duygu alanını ayırmak istemektedir.

Osmanlı aydınının birçoğunda görülen devlet ile ümmetin kader birliği ettiğine dair inancı Ahmet Naim de paylaşmıştır. Bora'ya (2009: 14) göre bu dönemin İslamcılığı proto-milliyetçilik işlevi görmüş, devleti ve ümmeti bir arada tutma gayesini gütmüştür. Bu devleti ve ümmeti bir arada tutma gayesi, Ahmet Naim'in Türkçülüğü eleştirisinin aynı zamanda siyasi yönünü oluşturmaktadır. Devlet ve ümmet Osmanlı nizamı içinde birlik olmuş iken onu Türkleştirmek nizamın sonu aynı zamanda dinin sonu anlamına gelmektedir. Sonuçta, Ahmet Naim'in Türkçülere yönelik eleştirisi, Osmanlı kimliğinin parçalanmasına dair aktüel ve politik bir kaygısını taşımaktadır. Ahmet Naim, din ve devlet birlikteliği açısından da Türkçülüğü Osmanlı Devleti'nin parçalanması olarak görmektedir.

\section{Ahmet Naim'in Milliyetçilik Eleştirisine Girişi}

Ahmet Naim'in milliyetçilik hareketlerini odak konusu yapan dört makalesi bulunmaktadır. Üslubun yumuşaklığı 
ve sertliği sanki yaklaşan savaşların ve ayrılışların haberlerini içinde taşımaktadır. Ahmet Naim'in sorunu, ittihat ve Osmanlı Devleti'nin bekasının güvence altına alınmasıdır. İttihat kaygısı, siyasal düşüncelerine bütünlük ve tutarlılık kazandıran temel bir sorundur. Dinsel bir dilin içinde daha çok ifade edilse bile ittihadın temel anlamını politik alan kazandırmaktadır.

II. Meşrutiyet'ten hemen sonra İttifak Dergisinde, 30 Ağustos 1908 yılında, “Arap İhvanımıza Bir Nasihatimiz" adlı ilk makalesinde Arap Kulübü'nün kurulması teşebbüsünden duyduğu rahatsızlığını ifade eder. Ahmet Naim, (2018: 344) cemiyetinin isminin "Arap" olmasının tefrikaya neden olacağını savunur:

"İnsaf ediniz. Biz bugün gayrımüslim vatandaşlarımızı râyet-i âdile-i Osmaniye altına cem' etmeye çalışıyoruz. Tanışalım, barışalım, sevişelim diye onları âguşumuza alıyoruz. Ecânibe bile kendimizi sevdirmeye gayret ediyoruz. Böyle bir sırada ihvân-1 müslimînin şakk-1 asâ-yı vahdeti îhâm ve hatta hafifçe işmâm eden bir nâm altında içtimâ etmek gibi bir cefâlarına tahammül edebilir miyiz?"

Ahmet Naim'in bu yazısında temel kaygısı, ilk olarak Müslümanların varlığını garanti altına alan Osmanlı Devleti'nin bekası, ikinci olarak da Müslümanların zayıflığının sonuçları etrafında biçimlenir. Metinde geçen övünme, müsavat, uhuvvet, vefa, ittihat, tefrika ve cemaat kavramları, metnin bütün kelimelerinin anlam kuruluşlarını sağlamaktadır. Metinde tefrika/ittihat, uhuvvet/düşmanlık, cemaat/ayrılık; vefa/zulum çiftleri metnin ruhunu oluşturmaktadır. İkililiklerle düşünme, Balkan ve I. Cihan Harbi'nden önceki Osmanlı aydının tipik bir tarzıdır. Osmanlı Devleti, bu ikililiğin merkezi bir alanıdır. Daha önceden Kanunu-1 Esasi ve gayri Müslimlerle ilgili eşitlik düşüncesini savunusunda görülebileceği gibi siyasal alanın zorunluluğu teolojik sorunları arka plana itmektedir. Siyasal bir proje olarak Osmanlılık kimliğinin başarısı İslamcıların kendi varlıklarını koruyan Osmanlı Devleti'nin bekası açısından elzem görülmektedir. Özellikle "neşem kaçtı", "masumane, terakki-perverâne bir maksada istinat ettiğinden şüphe yok", "su'-i niyet şaibesi görmekten bile Allah'a sığınırım” gibi kırmaktan korkan bir üslup göze çarpmaktadır. Bu safların netleşmesinden önce ittihadın sağlanması konusundaki umuda ve birleştirici bir dile dayanmaktadır.

Ahmet Naim'in (2018: 346-51) milliyetçilikle ilgili ikinci makalesi İttifak Dergisinin 17. sayısında, Eylül 1908 tarihinde yayınlanır. Bu makalede, İslam ve Arapların ayrılmaz ikili oluşturduğunu savunur. Abdulhamid döneminde, yaptıkları ile kötü anılan "Arap İzzet" ile Ebu'l Hüdâ'nın eleştiri konusu yapılmasının Araplara yönelik olumsuz tutumu barındırmadığını düşünür. Eleştirinin "idare-i sâbıka-i müstebiddenin" tecessüm etmiş kötülüğün iki heykeli olmalarından kaynaklandığını savunur. Bu iki zata yapılan eleştiriyi değerlendiren Ahmet Naim, kişilerin yaptıkları ile kavimleri arasında ayrım yapılması gerektiğini savunur. Temel amac1, kötü tipler üzerinden millet algısının oluşturulmasını önlemektir. "Bir Arap bir Türk kadar sadık olamaz" diyen gazete hangisi ise hezeyân etmiştir." diyerek milletler hakkında tahkirlerin yanlış olduğunu söyler.
Ahmet Naim, (2018: 348-49) dönemin ruhuna uygun olarak tartışmalarda, Türk, Arap ve Arnavut'tan bahsetmeyi daha uygun görür. Araplar ile Türkler arasında münasebet Osmanlı Devleti'nin ittihadını belirlemede oldukça önemlidir. "Daima Türkler Arapları üstat, Araplar Türkleri kendilerine zahîr-i kavî bilmişlerdir. Türk Arapsız edememiş, Arap Türksüz yaşamamıştır. İşte hakikat budur.” Geçmişteki medeniyet tecrübesi ve ilimleri açısından Arapları öven Ahmet Naim, Türkleri de bu mirası koruyan kudret olarak ifade eder. "Bu iki kavim sâir akvâm-ı İslâmiye gibi birbirine o kadar muhtelit u mümtezicdir ki bugünkü devr-i Meşrutiyet'te Arabın mebusu Türk, Türkün mebusu Arap olmakta hiçbir kimse garâbet görmez. Türk mebusunun mecliste re'yi ne kuvvette ise Arap mebusunun da re'yi o kuvvettedir." Ahmet Naim, bu makalede de İslam ile Osmanl kimliğinin çıkarları arasında uzlaşı ve çakışma görür. Makalenin temel amaçlarından biri de Türklerin Araplara karşı olumsuz hisse sahip olduğuna dair bazı neşriyatta ve yerlerde ifade edilen sözlerin yanlışlığını ve yalan olduğunu gösterme gayretidir. Arap ittihadı ile ilgili bir haberden dolayı "siyaset-i umumiye ile menâfi"-i İslâmiyeden gafil, menâfi ‘-i Osmaniyeye gayr-i hâdim" olduğunu söylediği Millet Gazetesi’ni eleştirmektedir. Ahmet Naim, Arap İttihad Kulübü'nün maksadının Müslim ve gayri Müslim Osmanlı evlatlarının "Osmanlı İttihâd ve Terakki Cemiyeti'ne muâvenet" olmasından memnuniyet duyduğunu belirtmektedir. "Maksat mülk $\ddot{u}$ vatana, millet-i Osmaniyeye hizmet olunca bu hizmet her ne şekl ü surette tecelli ederse etsin makbuldür, hoştur." demektedir.

"Vahdet- $i$ milliye uğrunda terk-i asabiyet $\ddot{u}$ kavmiyet faziletini bi'l-cümle akvâm-l muhtelife-i Osmaniyede görmek için asabiyet ü kavmiyet fikrinden müberrâ olan bu cemiyetinizin..." Bu makale incelendiğinde Ahmet Naim, Müslümanın akibetyle onun kudreti olarak gördüğü Osmanlı Devleti'nin bekası arasında bağlantı kurmaktadır. $\mathrm{Bu}$ açıdan, Ahmet Naim örneğinde, İslamcıları, Osmanlı ve Osmanlıcılık kimliğinden ayrı düşünmek mümkün değildir. Çünkü milliyetçiliğe karşı eleştirilerini sadece dini bir dil ile değil, Osmanlı Devleti'nin bekasına dayalı bir var olma bilinciyle yapmaktadırlar. Hatta bazı yerlerde iki açıdan da aynı şey ifade edilir. "O cemaatten ayrılmayınız..." ibareleriyle "kastettiğim cemaat Müslümanlara göre cemaat-i müslimîndir. Gayrimüslimlere göre millet-i Osmaniyedir." "Evvelki itirazım camia-i İslâmiye nokta-i nazarından idi. Şimdi ise camia-i Osmaniye nokta-i nazarından aynı itirazda bulunuyorum." (Ahmet Naim, 2018: 350/349).

Milliyetçiliği eleştiren üçüncü çalışması, 26 Eylül 1912 yılında Sebîlürreşâd'ın 212. sayısında, yani I. Balkan Savaşı'ndan iki hafta önce, Mehmet Akif'in "Hepiniz toptan Allah'ın ipine sarılın" ayetinin tefsirinden sonra yer alan "Hadis" adlı makalesidir. Ahmet Naim, (2017: 65-67) bu makalesinde, "Asabiyet davasını güden bizden değildir." hadisini yorumlar. Bu makalenin amacını, "Türkçülere açılan dindarane bir mücahade" olarak değerlendirmektedir. Makalenin en önemli özelliği, İslamcılar ile Türkçüler arasında var olan, kısmen İttihat ve Terakki'den kaynaklanan birliğin ortadan kalktığına yönelik işaretler taşımasıdır. 
Ahmet Naim, (2017: 65-69) milliyetçilik davasını takip edenlerin İslam'ın emin ve korunan dairesine dâhil olup olmadıkları konusunda şüphe olduğunu söyleyerek, meseleyi cehalete bağlar. Bu vakitte, tereddüt ve cehalet kavramlarının tartışmada merkezi yeri işgal etmesi, keskin sınırlarla belirlenmiş ayrıştırıcı kavmiyet tartışmasını sürdürmenin doğru olmadığına dair kanaatin devam etmesiyle ilgilidir. Diğer tarafi hâlâ kendisine çekme umudunu da taşıyan strateji burada önemli rol oynamaktadır. Bu makalede, "bizden değil" konusunda karar vermeyi erteleyen "cehalet" söz konusudur. Ancak, failin belirsizliğine rağmen asabiyetin tanımı kavmiyetçilik anlamına gelecek şekilde sert bir şekilde yapılmıştır. Peygamberin sert bir şekilde nehyettiği (nehy-i şedîd) asabiyet, Müslümanların yurtlarının bekasını yıkan, aralarında kanlı bir mücadeleye yol açan etken olarak tanımlanmaktadır. Burada kavramın omurgasını "tecavüz" etme oluşturmaktadır. Bu kavram, din kardeşlerinin eşitlikten kaynaklanan haklarını ihlal etme anlamında kullanılmıştır. Tecavüz-eşitlik ikilemi içinde asabiyet, kardeşliğe dayalı eşitliği ortadan kaldıran eylem olarak değerlendirilir. Eşitlikte tarihsel olarak kendimiz için istediğimiz iyilikleri diğerleri için de isteme, ortak arzu duymayı da içine alacak şekilde ifade edilir. İslami terbiye açısından ise bütün Müslümanların "rûh-1 vahîd" olması en büyük temel amaçtır. Bu durumda eşitlik, İslami terbiyenin bir sonucu olarak Müslümanların hal ve arzularında ortaklıklarını ifade etmektedir. Eşitlik değeri ile kardeşlik statüsü arasında sürekli bir ilişkiyi muhafaza ederek yazar. "Her biri; müslümanlar şöyle böyle olsun! der de, hiç biri; Benim kavmim şöyle olsun, böyle olsun! diyemez." diyerek, "arzuda bir" duygusunu nifak ve ayrılık isteğinin karşısına koyar. Arap, Türk ve Arnavut, üzerinden meseleyi değerlendirmesi politik alanın dinsel bir dile nüfuz ettiğini göstermektedir. $\mathrm{Bu}$ halkların siyasete yönelik ulusal taleplerine karşı Osmanlının değerini vurgulama hissine kapılır. "İslâm'ın son ilticâgâhı olan vatan-1 azîimiz"'in milliyetçi teşebbüslerden dolayı kalbinde kırılma olduğunu ifade eder. Osmanlının, "son ilticâgâh" tasvirinde 1856 yllından beri düzenli olarak yerinden yurdundan kopan birçok millete vatan olmasının derin izleri bulunmaktadır. Milliyetçilik, tarihsel sahnede Peygamberden ayrılma, cahiliyetin dirilmesi olarak görülür. Çünkü bu hareketler, ona göre Müslümanları, özellikle Osmanlıyı "hufre-i helake" götürür. Dolayısıyla, Ahmet Naim, tekrar, bu konuyu Müslümanların cehaletine, bilmezliğine vererek, eleştirel üslubunu dini kimliğin bütünleştirici çerçevesi içinde kalarak yapmaya çalışmaktadır. Sınır daha ihlal edilmemiştir. Milliyetçi hareketlerin peygamberden ayrılma ve dünyevi saadetlerini ortadan kaldırma şeklinde düşünülmesi, politik olan ile dinselliğin Müslümanların çıkarı konusunda çakıştığını gösterir. Bu çakışmayı sağlayan ise Osmanlı Devleti'dir. Çünkü Osmanlı "son İslâm yurdu"dur. Osmanlı Devleti yıkılırsa "İslâm'ın bî-nişân olarak yalnız târîh kitaplarının mevzûâtı miyânında kalmasıdır." "Dîn-i İslâm'ın işte bunun kadar buğzettiği, bundan ziyâde nefret ettiği şey yoktur." Devletin varlığının dinin anlaşılmasına bu kadar dâhil olması, ontolojik olarak Müslümanların kendi varlıklarını siyasal aygıta bağlamaları gibi yeni bir durumu ifade eder. Ahmet Naim, (2017: 67) reel politik bir durumun üstesinden gelmeyi dinsel bir meselenin çözümüne bağlar. Çünkü ittihat, kalbi bir şey olarak dinde yer almasına rağmen, bunu siyasal bir dünyaya taşır. Gerekçesi ise oldukça açıktır: "Acaba kendi kılıçlarımız düşman kılıçlarının araya girmesine meydan bırakacak $m \imath$ ?"

Ahmet Naim'in milliyetçilik ile ilgili yazılarında kullandığı üslup ve tarz zaman içinde değişmektedir. Bu değişen üslup, devrin siyasi atmosferini yansıttığı gibi aynı zamanda İslamcılık ile milliyetçilik düşüncesi arasında var olan çatışma ve rekabetin şiddetini de yansıtmaktadır. Örneğin 1908 yılında yayınlanan birinci ve ikinci makalesinde nasihat içeren bir üslup ile Araplara seslenmektedir. Bu tenkidin Müslümanların birliği için çalışan "gayur bir kalpten" çıktığını söylemektedir. Üslup yanlış anlaşılmaktan endişe duyan bir kişinin doğru bildiği düşüncesini, kimseyi incitmeden söyleme gayretinin izlerini taşımaktadır. Arap Kulübü'nün Naim'e verdiği cevabında, öncelikle onun Arap kavmine karşı duyduğu hissiyatından dolayı teşekkür etmesi 1908 'de genel olarak İslamcılık ile milliyetçi düşünceler arasında gerilimli ilişkilerin görülmediğinin işaretidir. Üçüncü makale, 1912 yılında Sebîlürreşâd dergisinde yayınlanmıştır. Üslup daha sertleşmekte ve metnin temel amacı milliyetçilik yapan "bizden değildir"i karşı tarafa ispat etmektir. Bu makalede taraf ve özne belirgin değildir. Yakında çıkacak Balkan Savaşı'nın gerilimi, taraf ve özneyi daha da netleştirecektir.

Kara (2001: 31), İslamcıların 1912 yılına kadar milliyetçi düşünceleri eleştirmemelerini; onları ciddiye almamaları, İttihad Terakki'den çekinmeleri, fitne çıkarmaktan korkmaları gibi nedenlere bağlar. Kanaatimce bu sav doğru değildir. Ahmet Naim'in birinci makalesinde üslubu ve içeriği milliyetçilere karşı "doğru yolu" gösterme konusunda kaygısını ifade eder. İttihad ve tefrika arasında kurulan kuvvetli ve zayıf olma ikililiği de baştan itibaren muhatabın ciddiye alındığını göstermiştir. Hep ciddiye alınacaktır. Kudretin temeli olan ittihadı bozan bir unsur olarak milliyetçiliği, Akif ve Ahmet Naim, "nehy-i şedid" olarak değerlendirmiştir. Osmanlı kimliğine vurgu da bu dikkate almanın işaretidir.

Ahmet Naim'in milliyetçilik eleştirisindeki radikal tutumu yıllar geçtikçe artmaktadır. Osmanlı kimliği ile İslamcı kimlik arasında beka açısından kurulan ilişki, bütün herkes tarafından kabul edildiğinden tartışma sınırları belirsiz bir alanda din dilinin meşruiyeti içinde devam etmektedir. Ahmet Ağaoğlu, (1997: 583-86) Ahmet Naim'e verdiği cevapta Ahmet Naim'in dini kavramları yanlış kullandığına dair eleştirisi, milliyetçi hareketin din dili içinde kendine yer bulma isteğinin canlı olduğunu göstermektedir.

$\mathrm{Bu}$ yüzyılda milliyetçilik, anti-emperyalist bir hareket olarak da düşünülmektedir. Bu nedenle, İslamcılar İslam dünyasındaki Batılı sömürgecilere karşı geliştirilen bütün bağımsız hareketlerini desteklemektedir. Özellikle, Sebîlürreşâd'ın düzenli olarak İslam dünyasından haberler vermesi bu desteğin ifadesidir. Akçura, Ağaoğlu, Gökalp'ın İslamcı Afgani'nin ittihad-ı İslam için yerel birimlerin kendi bağımsızlıklarını kazanmasına dayalı tedricilik düşüncesine sempatik tutumları, din ve vatan sevgisinin karışımından doğan bağımsızlık düşüncesinin varlığıyla izah edilebilir. Sol düşünceleri ile tanınan Alexander Helphand (Parvus) un Türk Yurdu'nda 16, 
Osmanlıcı İçtihad Dergisinde ise 6 makale yazması, Ağaoğlu'nun Sebîlürreşâd'ta 30 makalesinin yayınlanması (Gündüz, 2007: 76, 368, 224) İslamcılar ile milliyetçi hatta solcular arasında vicdani ve mücadele ortaklığına dayalı bir zeminin varlığını gösterir.

1908 yılında kurulan Türk Derneği'nin amaçları arasında "Millet-i Osmaniye"nin geliştirilmesi bulunmaktadır (Akai, 2008: 42). Bu ifade göstermektedir ki 1908 yılında milliyetçi düşüncede Osmanlı'dan kopuş ve yeni ulus yaratma arzusu açık değildir. Ancak 1908 ile 1914 yılları arasında matbuatta meydana gelen yeni milliyetçi gelişmeler ve İTC'ne karşı bütün kesimlerde var olan genel hoşnutsuzluk, İslamcı düşünce ile Türkçü düşünce arasında safların belirginleşmesini sağlamış, safları ayırmıştır. Bu koşullarda, Ahmet Naim'in 1914 yılında yayınlanan aşağıda değerlendirilen makalesi İslamcıların milliyetçi düşüncelere karşı aldığı ilk ciddi tavır sayılmalıdır (Hansu, 2007: 141).

Bütün olaylara rağmen onları gayri Müslimlere karşı tercih etmişlerdir. 1920 yılında, Nursi'nin (2004: 267) partiye "şedid bir muarız" olmasına rağmen, düşmanların onlara şiddetli hücumlarından ve "Antranik ile beraber Enver'e, Venizelos ile beraber Said Halim'e vurmam." düşüncesi çatışmayı kafir-Müslim açısından düşündüklerini gösterir. Said Nursi'nin (2004: 15) ittihatçılar hakkında “Onların bir kısmı İslam fedaileridir, bir kısmı de selamet-i millet fedaileridir." sözleri, İslamcılar ile milliyetçiler arasındaki bağların tamamen kopmadığının işaretidir.

\section{Balkan Savaşları ve Ayrılığın İşaretleri}

Milliyetçilik tek başına arz-1 endam etmeden önce din ile yakın bir teması vardı. Osmanlı toplumu için İslam, meşruiyeti sağlayan önemi bir otoritedir. İslam ve Türk kelimelerinin toplumsal çağrışımları, Türk milliyetçilerin Türk kavramı kadar İslam kavramına vurgu yapmalarını sağlıyordu. Çoğu Türklerin Müslüman olması İslam-Türk vurgusunun şiddetini artırıyordu. Türklük ve İslam arasındaki bu aynilik sadece Türkler arasında geçerli değildi. Çarlık döneminde Türkçülük yapanların kayıtlara Türkçülük kisvesi altında İslamcılık yaptıkları şeklinde geçmesi ve Rusya'da milliyetçi hareketlerin konferanslarını, Rusya Türkleri yerine, Rusya Müslümanları Konferansı adını vermeleri de onların bu konuda yaşadıkları ikilemi göstermektedir (Akgün ve Çalış, 2002: 589).

Balkan Savaşı ve sonuçları Türk milliyetçi düşüncesinin gelişiminde önemli bir devri temsil eder. "Türk milliyetçiliği aydınlar ve gençler üzerinde yayılmaya Balkan Savaşlar'nda uğranilan bozgunlarla başlar. Pantürkçüler bu dönemde bu bozgunu telafi etmek için Cengiz Han, Tamurlenk, Babur gibi yitik kahramanlar ve düşler sunar" (Georgeon, 2002: 27). Bu dönemin milliyetçiliğinin temel özelliklerinden biri kurtuluşu amaçlayan bir milliyetçilik olmasıdır. Semboller de bu açıdan oluşturulmuştur. Renan, "Ortak acı sevinçten daha birleştiricidir. Milli hatıralar arasında yaslar zaferlerden daha makbuldur. Zira yas, görev yükler, ortak çabayı emreder." der. Balkan Savaşı Türk Milliyetçiliği üzerinde romantik bir dünya ve görev duygusu oluşturmuştur (Georgeon: 2009:108). Balkan Savaşı, Osmanlıcılık politikasının geçerli olmadığını ve ittihat-ı İslam politikalarının Müslüman halklar üzerinde etkisinin azaldığı şeklinde yorumlanmıştır. Bu iki sonuç, Türkçülük akımının İslamcılık düşüncesi karşısında güçlenmesine neden oldu. Milliyetçilik sadece Osmanlıcılık düşüncesine değil, Osmanlı kimliğini Müslümanlar için fiili ittihat-1 İslam olarak gören İslamcı düşünceyi de karşısına almaya başladı.

Bu koşullar içinde 1914 yılında yazılan makale, İslamcılar açısından kopuşun kaçınılmaz olduğunu ilan etmektir. Bu kopuşun nedenlerini dergilerin tedrici değişen politikalarında görmek mümkündür. Örneğin, başlangıçta Selanik’te çıkan Genç Kalemler (1910) adlı dergi dilde milliyetçiliği savunurken aynı zamanda Osmanlı Devleti'nin birliğini korumaya büyük önem vermektedir. Ancak daha sonra çıkan Osmanlıcı olmayan pantürkist Türk Yurdu dergisi (1912) daha radikal milliyetçi görüşleri savunmaktadır. Türk Yurdu'nun "refiki" olarak İslam Mecmuası'nın çıkması, artık İslamcılar ile Türkçülerin aynı dergide yazı yazmalarının sona erdiğinin önemli bir işaretidir. Türkçüler arasında var olan dergileşme, ITTC'nin önderliğindeki siyasal gelişmenin matbuata yansımasıdır. Özellikle İslam Mecmuası'nda Ziya Gökalp önemli görevler almış ve dergi Kur'anı'ı Kerim'in çevirilerini yayınlanmıştır. Sebîlürreşâd'da yazan Şemseddin Günaltay gibi bazı yazarların İslam Mecmuası'nda yazmaya başlaması da İslamcılar ile Türkçüler arsında var olan belirsizlik alanını ortadan kaldırmıştır (Arai, 2008: 132136).

Ahmet Naim'in düşünce ve üslubundaki sertleşmenin nedeni milliyetçiliğin bu yeni etkisiydi. Milliyet ve milliyet ülküsü, İslam ve ittihad-1 İslam düşüncesinin yerini almakta, bundan daha önemlisi, siyaset üstü bir anlayış sağlayarak üretilen politikalara meşruiyetini sağlamaktadır. Milliyetçilik, ideolojiler üstü bir temel ilke sağladığı, vatanın birliğinin korunmasının ve ulusal çıkarın ne olduğuna dair politikanın belirlenmesinde temel olarak, yeni meta-ideolojik işlevini İslamcılıktan devralmak istemekteydi.

“Dava-y1 Kavmiyet” makalesi, özellikle Rusya'dan gelip Osmanlı Devleti'nde Türkçülük akımını geliştirmeye çalışan kişiler için önemliydi. Çünkü Rusya Müslümanları içinde pantürkizm ile panislamizm birlikte gelişmiş ve birbirlerini dışlamamıştır (Georgoen, 2009: 6). Türk Yurdu dergisinin refiki Tercüman adlı gazetenin sahibi Gaspıralı'ın en önemli hayali 'Dünya Müslümanlar Kongresi'ni düzenlemektir. Bunun için En- Nahza adlı Arapça gazete neşreder (Akgün ve Çalış, 2002: 589). Bu veriler 1şı̆̆ında, Ahmet Naim'in pantürkizm, milliyetçilik ve İslam arasına koymaya çalıştığı mesafenin, milliyetçi düşünce açısından ne kadar olumsuz olduğunu anlamak kolaydir.

Bu makalesinde, Ahmet Naim, milliyetçiliği "bizden değildir" gibi temel ve ayrıştırıcı bir ilke üzerinden değerlendirmektedir. $\mathrm{Bu}$; nasihatten, ayrıştırıcı eleştirel bir üsluba dönmenin iki temel etken tarafindan sağlandığ ileri sürülebilir:

i. İlk olarak 1908 ile 1914 dönemleri arasında matbuatta ve siyasi alanda gözüken gelişmelerden,

ii. İslamcılar açısından milliyetçik, tefrikanın dışında, modernleşme ile ilişkisinin daha derin olarak kavranmasından kaynaklanmıştır. 
İslamcılar için bu geç farkına varmanın nedeni milliyetçiliğin 19. yüzyılda anti-emperyalist karakterinin baskın olmasıdır. Daha önceden İslamcıların İTC'ne yönelik yapılan değerlendirmelerde, cemiyetin antiemperyalist tarafının İslamcılar açısından önemsendiği savunulmuştu. Oysa 20. yüzyılda milliyetçi ideolojiler, aynı zamanda sekülerleşme ve modernleşmenin taşıyıcısıyd1. "Milliyetçilik Türk modernleşmesinin en önemli unsuru ve aynı zamanda diğer unsurların da hayata geçirilmesinde önemli bir zemini oluşturmaktadır. Milliyetçilik, siyasal ideolojiler zemininde bir fundemantalizm etkisine sahip, siyaset-ötesi ve ideolojiler üstü bir temel ilk hükmündedir" (Bora, 2002: 15).

Tartışma basit bir şekilde kavmiyetçilik üzerinde yoğunlaşsa bile esas tartışma, dil, hars, medeniyet üzerine yapılmaktadır. Kavmiyetçiliğe karşı olanlar gerçekte harslara, dillere ve ulus devletlere karşı çıkıyorlardı.

\section{Ayrılığın İlanı: "İslam'da Dava-yı Kavmiyet"}

Ahmet Naim'in kavmiyetle ilgili dördüncü makalesi yayınlanmadan önce Süleyman Nazif ve Ahmet Ağaoğlu arasında milliyetçilik üzerine tartışma olur. Süleyman Nazif, Ağaoğlu'nun Türk Yurdu'nda çıkan bir dizi yazılarını eleştirmektedir. Özellikle, Cengiz Han adlı yazılarına karşı Nazif, İçtihad Dergisinin 30 Temmuz 1913 yılında çıkan 72. sayısında "Cingiz Hastalığı”" diye eleştirel bir yazı yazar (Gündüz, 2007: 90-91). Ağaoğlu, bu eleştirilere karşı, milliyetçi hareketin Osmanlı Devleti'ne zarar vermeyeceğini ve diğer ulusların Osmanlı ile bağlantılarını zayıflatmayacağını ileri sürer. Ona göre Türk milliyetçi hareketi politik bir hareket niteliği taşımadığından, Osmanlı Devleti'nin egemenliğine tehdit oluşturmamaktadır. Milliyetçilik, etik ve sosyal bir hareket olarak Türkler için olduğu gibi diğer milletler için de tamamen hümanist amaçlar taşıyan bir harekettir. Ağaoğlu, milliyetçi hareketlerin Osmanlı Devleti'ni bölmek ve ayırmak değil bilakis, birlik için bir avantaj olduğunu ileri sürer. Türkler ve Araplar arasında ulusal bilincin artmasıyla birlikte aynı amaç ve ideal için mücadele edebilirler. Bu mücadeleyle birbirlerini daha iyi anlarlar. Ağaoğlu'na göre Türkler, Araplar ve diğer milletler, ulusal ideallerini anladıklarında ve bu amaçlar için gayret sarf ettiklerinde, Osmanlı Devleti'nden kopmanın onların ölümü olduğunu dolayısıyla birlikte yaşamanın gerekliliğini daha iyi anlarlar (Soysal, 1986: 111-112).

İslam Mecmuası'nda İTC'ne yakın olan Musa Kazım kardeşliğin önemi ve ihmalinin sonuçları üzerinde bir makale yazmıştır. Bunun üzerine, Takip ve Tenkid mecmualarının sahibi olan Nüzhet Sabit'in Musa Kazım'ın makalesiyle ilgili “İslam'da milliyetçilik var mı varsa bunun sinırları nelerdir?" sorularını sorar. Ancak Musa Kazım, bu sorulara cevap vermez. Ahmet Naim, 23 Nisan 1914 tarihinde, Sebîlürreşâd Dergisi'nde (2018: 112) biraz da alaycı bir şekilde, Türk Yurdu'na yakın olan İslam Mecmuasının bu sorular karşısında refikini gücendirmek istemediğinden dolayı, ihtiyar-1 sukut ettiğini söyler. Ahmet Naim'in makalesinin üst başlı̆̆ı "İslâm'da Da'vâ-yı Kavmiyyet", alt başlı̆̆ı ise 'Ta'kīb ve Tenfîz Mecmûası Sâhıbı Nüzhet Sâbıt Beyefendı'ye adını taşıması, bu görevi üzerine aldığını ifade eder. Ahmet Naim'in, kendisine sorulmamış sorulara cevap vermesi, artık ideolojilerin sınırlarını belirlemenin gereğiyle ilgilidir.

Düşüncemize göre Ahmet Naim'in teşebbüsü, Balkan Savaşları'nın sonuçlarını telafi etme yerine onu daha da derinleştirmektedir. $\mathrm{Bu}$ teşebbüs, İslamcıların ittihad-1 Osmanî çabalarına karşı gelmek anlamı da taşımaktadır. Çünkü onlar bütün hareketlere karşı 1lımlı olmakla bu işi yürütebileceklerinin farkındadırlar. Nitekim 1908 yılında, Sirâtımüstakîm'de (2012: 314, 302) Türk Derneğinin Kuruluşu ve Nizamnamesini yayınlamıştı. Nizamname'nin 2. maddesi, derneğin, Türklerin geçmişini, lisanını, edebiyat, etnografya, etnoloji, coğrafya, eski ve yeni medeniyetlerini araştırma ve yayınlama; Türkçenin sade ve güzel bir lisan olmasına çalışma amacı taşıdığını ifade etmektedir. 4. maddesi, din ve cinsiyet ayrımı gütmeden derneğe kayıt olunabileceğini düzenlemektedir. Bir sonraki sayısında Sebîlürreşâd dergisi nizamnameyi ilan etmekle bahtiyar olduğunu söyler. 6 yıl sonra yapılan Ahmet Naim'in bu eleştirisi, İslamcıların ılımlı tavırlarını terk edeceklerinin işaretidir.

Ahmet Naim, kavmiyet davası olarak makalenin başlığını koyar, bu başlık, Musa Kazım ve Nüzhet Sabit beyin açıklamalarından, sorularından alınmıştır. Makalenin yayınlanma tarihi (1914) felsefi ve dini bir tartışmadan daha çok sorunun politik bir alanla ilgili olduğunu, devletin bekası açısından sorunlara yaklaşıldığını işaret eder. Öncelikle şunu vurgulamak gerekir. Tarih, metnin bütün dil dışı bağlamı örgütlediği için lugavi anlam kadar tarih de metnin anlamını yeniden inşa eder. Bu durumda metnin çerçevesini, devletin bekası ve içerideki birliği etkileyecek olumsuz ayrılıklar oluşturmaktadır. Sertlik, yaklaşan savaşın ayak seslerini duymayla da ilgilidir. Ama yine de makalenin sahip olduğu amaç, Ahmet Naim'in üslubu tarafindan baştan itibaren kusurlu hale dönüştürülmüştür. Ayrılıkların fark edilmeye başladığı bu dönemde sert eleştirinin yapılması, geçişkenlik ve belirsizliği ortadan kaldırmıştır. Oysa ideolojiler arasındaki belirsizlik, ittihadı sağlamamasına rağmen, hiç olmazsa, çatışmayı ortadan kaldırmaktaydı.

Metin, tezleri ve delilleri açısından iki bölüme ayrılır. İlk bölümde, "ittihat" kavramı, dinsel açıdan yorumlanmaktadır. Kavmiyetçilik ile Batılı değerler arasında bağlantı vurgulanmaktadır. İtihadın siyasal birlik ve batıcı değerlere karşı koyma anlamına gelen ikili anlamı, Ahmet Naim'in anlaşılmasında temel bir faktördür. Naim'in milliyetçilik değerlendirmesinde temel kavram bu ikili anlama sahip olan ittihat fikridir. Bu birlik düşüncesi Müslüman halkları temel aldığı için siyasal; İslam dişı geçmiş ve Batılı değerlere karşı koyduğu için de toplumsal, kültürel içeriklidir. İki içerikli ittihat anlayışı, metne bütünlük sağlayan temel etkendir. İttihad-1 İslam, ittihad-1 anasırı içermektedir. Ahmet Naim'in düşüncesinde Osmanlılık, İttihad-1 İslam düşüncesinden taviz vermek değil, bilakis ittihadın gerçekleşmesine imkân tanıyan bir düşüncedir. Çetinsaya da (2009: 268) ittihad-1 İslami'ye taraftar olanlar için, “ittihad-1 İslami’yi ittihad-1 Osmanî içinde aramaya çalışmışlardır.' der.

Ahmet Naim, (2018: 112-3) makalenin ilk bölümünde, Balkan Savaşı'ndan sonra Arnavut'un ayrılmasının sonuçlarını, Osmanlı aydınları üzerindeki etkisini hatırlatmaktadır. Başta, Kürtleri "milliyetçi hastalıktan" 
uzak bir halk olarak değerlendirmektedir. Ahmet Naim, (2018:116) Türkçülük hareketini ve aydınlarını ikiye ayırmaktadır: Halis Türkçüler ile Türk İslamcılar. Ahmet Naim'in milliyetçiler arsında yaptığı bu ayrım Bora tarafindan “Balkan savaşı'ndan sonra Islamclar gayri ihtiyari olarak milliyetçiliğin oluşumunu ve içeriğini Islami açıdan denetleme, daha doğrusu buna şerh düşme konumunda kalmışlardır. Babanzade'nin ayrımı bu denetimin asli ve bugüne kadar uzanan ölçütü oldu." (Bora, 2009:114) şeklinde değerlendirilmiştir.

Ahmet Naim'in milliyetçiliği değerlendirmesinde asabiyet ve cahiliye kavramları merkezi bir yere sahiptir. Birinci kavram, Hz. Muhammed'in yaşadığı dönemdeki asabiyet davası güden kimseler ile milliyetçiler arasında bir analoji yapma imkânı kendisine sağlarken, cahiliye kavramı ise İslam öncesi döneme göndermede bulunduğu için, İslam'ın ortadan kaldırmak istediği şey olarak milliyetçiliği değerlendirmesine olanak tanımaktadır. Ancak, her iki kavrama güncel tartışmalarda karşılık bulma çabası, Gökalp ve Ağaoğlu'nun eleştirisinde ifade edildiği gibi, kendisini anakronik bir duruma da düşürmektedir.

Ahmet Naim (2018: 116) makalesinin muhatabının Türkçü İslamcilar olduğunu ifade eder. Onlara seslenmesinde, onların düşüncelerini İslami açıdan kontrol etmeyi amaçladığı anlaşılmaktadır. Bununla birlikte Halis Türkçülerin görüşlerini de aktararak onları Türk İslamcılara şikâyet eder. Ahmet Naim, (2018: 113) Halis Türkçülerin;

i. Zamanın milliyetçilik çağı olduğunu bu "seyl-i huruşan"a karşı koymanın mümkün olmadığını,

ii. İslam Türklerin dünyevi mutluluğunu sağlayamadığından ilk olarak Türk, sonra Müslüman olmak gerektiğini,

iii. İttihad-1 İslam mümkün olmadığından Türklerin yaşadığ 1 yerlerde millet ittihadının gözetilmesi gerektiğini, ileri sürdüklerini, söyleyerek onları eleştirir.

Bütün bunları, yeni bir mefkûre, yeni bir iman, yeni bir kavim, yeni bir millet oluşturmaya çalışmak olarak değerlendirmektedir. Ahmet Naim, bunların düşüncesine "tatlı hülya" diyerek istihza eder. Bunları muhatap almayacağını çünkü bunların "dinsizliği”" telkin ettiğini savunur. İsmini ve dinini yeni öğrendiği Orta Asya'daki Türklerle ittihadın ise imkânsız olduğunu vurgular.

Ahmet Naim, (2018: 116) ulusun oluşturulmasında önemli rolleri olan tarihsel köken bulma çabasına, yeni isimlendirmelere ve milliyetçi düşüncenin kurtuluş mitolojisini farklı yerlerde aramasına karşıdır. Ahmet Naim, "Halis Türkçüler"i Turan hayali kurmakla eleştirirken, kanaatimce, romantizm ile milliyetçilik arasındaki ilişkinin gücünü küçümsemektedir. Oysa Türk milliyetçiliğinin en güçlü yanı romantizmidir. Ağaoğlu, hayal'i bir güç olarak kullanır. "Hayal kadar vasi ve yine hayal kadar mübhem olan Türk aleminin hudud-l hakikisini çizmekten müşkil bir şey yoktur" (Arai, 2008: 91). Osmanlı Devleti'nin çıkmaza girdiği bu dönemde düşlere açılan Turan gibi mekânların rolünü küçümsememek gerekir (Georgeon, 2009: 32). Türk milliyetçiliği tarihi haritaların ve simgesel temsillerin gelişmesiyle çağdaştır. Haritalar gerçeklerin simgesel temsili olarak kalmaz, düşleri desteklemeye yarar (Georgeon, 2002: 27).

Ahmet Naim (2018: 116) Türkçü İslamcılarla dertleşebileceğini, bunların da Müslümanları kırmak istemediklerini düşündüğünden, bunlarla konuşulabileceğini düşünür. Türkçü İslamcıların;

i. Türklük akımının İslami davayı güçlendireceği, dolayısıyla milliyetçilik akımının İslam'a aykırı olmadığı düşüncesini, (Bu düşünceyi "çifte mefkûre", "hatta üç mefkure sahibi olmak", "hem yardan hem de serden vazgeçmeme" diye tasvir eder.).

ii. Milliyetçilik davasında Türklerin Arap ve Arnavut milliyetçilerinden sonra bu akıma dâhil olduğunu, dolayısıyla Türkler açısından zorunlu olduğu iddialarını,

iii. Cengiz'in kahramanlıkları ve Ergenekon'dan çıkışın kutlanması gibi tarihin yeniden okunup yeni isimler, bayramlar ve kahramanların ihdas edilmesi gerektiği düşüncelerini, eleştirir.

Ahmet Naim, (2018: 117) Türkçü-İslamcılara hitaben Türklerin İslam dünyasında yerlerinin önemli olduğunu, bu açıdan kendilerini önemli gören bu dünyadan ayrılmamaları gerektiğini savunur. Türklerin yönetici olarak önemlerine vurgu yaparak, "Diğer Müslümanların Türklere yardım etmesinin dini bir vazife" olduğunu savunur. Türklere yardımın dini bir vazife olduğunu vurgulaması Türkçü-İslamcıları ikna etmeye yönelik bir retorikten daha çok, millet-i hâkime ile Osmanlı Devleti'nin geleceği arasında var olan ortak kadere işaret etme çabasıdır. Bu düşünce, ittihad-ı İslamînin ittihad-1 Osmanî içinde aramasının sonucudur. Bu anlayış Ahmet Naim'in, düzen, birlik ve Osmanlı merkezli bir İslam Dünyası'nın varlığına yönelik inancını da ifade eder.

Ahmet Naim'e göre, (2018: 115-117) Türkçü İslamcıların sahip olduğu çifte gaye ile başarı elde edilemez. "Çatal kazık yere girmez." der. Ona göre Türklük gayesi, bütün Müslümanları kuşatamaz. Ayrıca, her iki gayeden birisini diğerinden fazla sevmek gerekir. Aşkta bölünme ve parçalanma olmaz. Bundan dolayı "Türklerin yüzünü Kabe'den Turan'a çevirmekten vazgeçiniz." Çünkü bu yönler birbirine zıttır, der. "Türk ve Müslüman" "Müslüman ve Türk" tabirlerini doğru bulmayan Ahmet Naim, birbirlerine "Ey Türk!" diyecek yerde "Ey Müslüman!" diye hitâb ediniz. Kendisine dâimâ Müslümanlı̆̆ından bahsediniz." demektedir. Ahmet Naim, Türklerin dil, kültür, medeniyet gibi özelliklerini geliştirmelerini ancak İslam'ın cevaz verdiği sınırları aşmamak koşuluyla kabul eder. Bununla birlikte, Ahmet Naim, hem Türklerin kendi tarihsel bilincini artırmaya dönük faaliyetleri önemserken hem de bu faaliyetin sonucu olarak gelişecek milli bilince karşı koymaya çalışmaktadır. Müslüman kimliğini de belki Cihan Harbi’nin olasılığgyla, bütün kimlikleri örtecek şekilde kullanmaktadır.

Ahmet Naim, din ile milletin tarihsel birliktelikten neşet eden kimlikleri dikkate almamakta, kendi anladığı dinin saf biçimine göre karar vermektedir. Geleneğin içinde biçimlenen İslam'ın halkın kültürel formu içinde 
geliştiğini görmezden gelmektedir. Nitekim Yahya Kemal ile tartışması da bunu göstermektedir. Doğrusu ittihad-1 İslam için yapılması gereken, kültürel düzeyi ifade eden Türklük, Kürtlük ve Arnavutluk ile İslam dini arasındaki kavramsal düzeyde aynileşmeyi yapabilmekti. Nitekim kendisi aşağıda ifade edileceği gibi İslam ile Arap kimliği arasında bir aynileşme yapmaktadır.

Ahmet Naim, (2018: 114) Türk-İslamcıları arafta kalmakla suçlamaktadır. Çünkü ona göre, Halis Türkçülerle tamamıyla uzlaşmadıkları için, halk bunların ne demek istediğini anlamamaktadır. Türk-İslamcıların geçmişte Türklere ilişkin bir töz varmış gibi düşünmelerini eleştirmektedir.

"Bir kere gāyenizi "hâlis Türkçüler"le tamâmıyla birleştiremediğiniz için ne demek istediğinizi lâyıkıyla anlamayan avâm-1 kavim ne yapacağını bilemiyor. Kendilerine: "Sizin atalarınız Kara Han'dır, Bozkurt Han'dır, Oğuz Han'dır, Cengiz Han'dır, Hülâgu Han'dır, bilmem ne handır" dediniz. Bin yıldan beri akvâm-1 sâire kanıyla karışa karışa Türklüğe lisândan başka bir nisbetleri kalmadığını, hattâ birçoklarının Türklüğü -sonradan öğrenilmiş lisândan dolayı- sırf ârızî bir şey olduğunu akıllarına bile getirmeyerek kendilerini hakīkaten bu saydığınız müşriklerin öz evlâdı zannediyorlar."

Ahmet Naim'in, kavimlerin karışmasından dolayı saf ırk bulunamayacağına dair bu görüşü, Ziya Gökalp tarafından da desteklenmektedir. Ziya Gökalp'ın kültür temelli 'Türkleşme' politikası, Ahmet Naim'in saf ırk olmayacağı düşüncesinin önemli bir destekçisidir. Çünkü "Türkleşme" bir özü değil, özü arındırmayı ya da onu yeniden tanımlamayı içerir.

"Türkleri istediğiniz kadar irşad ediniz. Yalnız dikkat ediniz ki, irşadlarınız, hizmetleriniz "Türklük" namına değil, "Müslümanlık” namına olsun.”(2018:115) Ahmet Naim'in, "Türklük" ile "Türk" arasında temel ayrım yapması, onun bütün milliyetçi değerlendirmesine sinmiş bir şekilde bulunur. Onun düşüncesinde Türk, somut bir varlık olarak ümmetin parçası iken, "Türklük” ümmetten ayrılmadır. Bu açıdan Türklere gereği gibi hizmet yapmayı dini bir vazife sayarken, kültürel bir içerik taşıyan Türklüğe karşıdır. Türklüğü tarihsel bir inşa olarak düşünür.

Makalenin ikinci bölümü, kutsal metinlerden hareket ederek milliyetçi düşünceyi eleştirir. Bu bölümde üç temel kavram üzerinden aktarımda bulunmaktadır: Tefrika, nifak ve dalâlet. Tefrika, cemaatin karşıtı olarak düşünülmektedir. Cemaatten ayrılmayı kayıp ve kaybetme olarak değerlendirmektedir. Nifak ise ittihadı tehdit eden davranıştır. Buna İslam tarihinden bolca örnek vermekte, kendi kavmi ve ailesiyle övünme olarak niteleyerek, cahiliye davası demektedir. Dalâlet ise dinin doğru kabul ettiğinden ayrılmanın itikadî bir dile dönüştürülmesidir. İlk ikisi temelde sosyal ve siyasal alandaki tavırla ilgili iken sonuncusu bu tavra bağlı olarak geliştirilen dinsel bir hesap verme niteliği taşımaktadır. Ahmet Naim'in (2018: 124) kendi savunduğu şeyi alt eden bazı unsurlar da bu bölümde yer almaktadır. Örneğin Arap milletine ait hadis olarak öne sürdükleri, İslam'ın kardeşliğe dayalı eşitlikçi düşünceyle çelişmektedir. "Araba muhabbet îmândır. Onlara buğz ise nifâktır." "Kureyş'e muhabbet îmândır.
Onlara buğz ise küfürdür. Araba muhabbet îmândır. Buğz küfürdür. Her kim Arabl severse beni sevmiş, her kim Araba buğz ederse bana buğz etmiş olur." "Arab zelîl olursa Íslâm zelîl olur." gibi sahihliği tartışmalı birçok hadisi kullanması, doğrusu İslam'ı belli bir etnik yapının tasallutuna hasretmesinden öte İslam'a giren milletleri baştan itibaren ikincil bir duruma düşürmektedir. Amacı ittihat olan bir makalenin bu konuda daha dikkatli olması gerekirdi. Türkçüler, Ahmet Naim, İbn Haldun'un Araplar için söylediklerine paralel olumsuz Arap imgesine dayalı eleştiride bulunsaydı, tartışma daha radikal sonuçlara yol açardı. Dolayısıyla, Ahmet Naim'in Araplar hakkında hadis diye bazı şeyleri aktarması öne sürdüklerinin temelini eşmektedir.

$\mathrm{Bu}$ bölümün güçlü kısmı Kur'an-1 Kerim ve hadislere dayalı kavmiyetçiliği eleştirmesidir. Zayıf kısmı ise ayetlerde ve hadislerde yer alan asabiyet, kabile asabiyeti (Evs-Hazrec / Ensar-Muhacir / Kahtan-Adnan) gibi konuların direk olarak millet tartışmalarına dâhil edilmesidir. II. Meşrutiyet dönemindeki milliyetçilik en azından bu kabileler arasındaki övünme ve soy asabiyetinden farklı bir içerik taşımaktadır. Övünme ve küçümseme gibi etik davranışları milliyetçilik için kullanmak en azından Türk Nizamnamesi'nin kuruluş amacını gösteren ikinci maddesiyle irtibatlı değildir. Ayrıca milliyetçiliğin Batılı ve sömürgelerdeki biçimi o günkü şartlarda farklıdır. Üçüncü dünya milliyetçiliği, toprakları işgal edilen ulusların milliyetçilikleri, diğerine değil, kendine atıfla inşa edilen bir milliyetçilik düşüncesidir.

Ahmet Naim, (2018: 117-9) kavmiyetçiliğin kendine yeni bir kök ve tarih bulmasına da karşıdır. Cengiz'in mukaddes yasası üzerine yapılan yeminleri ve 'mukaddes toprağına' dair terkibi eleştirmektedir. Bazı Türkçülerin eski isimlerini bırakıp Gündüz, Uyanık, Gök, Konur Bey gibi yeni isimler almasını, Peygamber'in yeni dine giren bazı kişilerin isimlerini değiştirmesi ile kıyas etmektedir. Şaman geleneğinin öne çıkması da Babanzade için mitolojik bir kaynak bulmak ile eş anlamlıdır. Ahmet Naim, Paskalya Bayramı'nın kendisini 'Ergenekon'dan çıkış bayramından daha 'mütehassıs' ettiğini alaycı bir şekilde ifade eder. Wallerstein de ulusun inşa edilmesinde resmi tören ve bayramların önemli olduğu düşüncesi ile Ahmet Naim' in 'Ergenekon'dan kurtuluşun bayramı' gibi yeni bayram törenleri ihdas edilmesi düşüncesi arasındaki benzerlik göze çarpmaktadır. Ahmet Naim, milliyetçi dili kendi içinde çözümlemesinde, birçok kusur olmasına rağmen, oldukça başarılıdır. Milletin 'hayali cemaat' olduğuna dair modern kuramlar ile Ahmet Naim'in görüşleri arasında benzerlikler bulunmaktadır. Ahmet Naim'in, ne yazık ki, bu kuramın öncüsü olma konusundaki hakkı yenilmiştir. Ahmet Naim'in düşüncesinde 1 rkçılığa tahammül gösterilmemesinin iki temel nedeni vardır. Irkçılığın;

i. En bariz vasfi olarak kendi milletini diğer milletlerden üstün görmesi ve bu üstünlüğü İslam'dan başka bir şey üzerinde temellendirmesidir.

ii. Bu düşüncenin siyasal ve ekonomik olarak ittihad-1 İslam düşüncesine karşı gelmesidir. $\mathrm{Bu}$ 1rkçılık tanımlamasında temel faktör, 1rkçılı̆̆ın dönemin ruhunu ifade eden "ittihat" düşüncesinden ayrışmayı ifade etmesidir. 
Milliyetçiler tarafından "millet" genelde iki şekilde tanımlanmaktadır: Birinci cevher olarak, ikincisi süreç olarak tanımlamadır. Ahmet Naim her iki tanımlama çabasına da karşıdır. Birinci olarak tümdengelimsel olarak sanki milletin geçmișten günümüze devam eden ve nesiller tarafından taşınan bir tözü varmış gibi tanımlanmasıdır. Şimdide mamul edilmiş millet anlayışının geçmişe yönelik yürütülmesidir (Balibar, 2007: 106). İkinci olarak millet kavramı, fabrikaya giren ham maddenin işlendikten sonra çıktı haline gelmesi gibi süreçteki değişimlerin dikkate alınarak kullanılmasıdır. Bu kullanımda ise millet tarihsel bir yürüyüş içinde değişip dönüşmekte, sürekli bir süreç içerisinde yeni özellikler alarak devam eden varlık olarak düşünülmektedir. $\mathrm{Bu}$ millet tanımlarından birincisi, kendini tarihsel bir öz ile ilişkilendirmekte iken diğeri, kendini tarihte inşa edilen olarak değerlendirmektedir. Ahmet Naim, 'tarihsel bir öz' iddialarından dolayı, "Halis Türkçüleri”; Türklüğü bir süreç olarak değerlendirdikleri ve daha sonraki uğrağı içinde İslam'1 da Türklüğün oluşumunda bir etken olarak düşündükleri için "Türkİslamcılar"1 hedef almaktadır. Bir başka açıdan töz/tarih/(Akçura), süreç/coğrafya/sosyoloji/(Gökalp) çizgisini eleştirmektedir.

Ahmet Naim'in bu makalede ağır ithamlarda bulunması bazı kesimler tarafından Kürt olmasına bağlanmıştır. Oysa metinin ruhunda ve lafzında böyle bir imayı bulmak mümkün değildir. Milliyetçi kesim de, makalenin hem Türkçülük yapanları hem de Türkleri aşağıladığını, Arapları ise övdüğünü iddia etmiştir (Hansu, 2007: 145).

\subsection{Kavram Tercihleri}

Tartışma kavramlar üzerinden devam etmektedir. Ahmet Naim'in makalesine cevap veren Ağaoğlu'nun makalesinin adı "Dava-yı Milliyet”tir. Gökalp kavmiyeti, siyasal meşruiyete veya bir modern ulusa göndermede bulunmayan, dar anlamda, içinde dilin öğrenildiği nesep açısından birbirine yakın insanları kapsayan şeklinde tanımlamaktadır (Gökalp, 2010a: 24). Geniş anlamda ise aynı dili konuşan insanlara tekabül eder. Gökalp kavmiyet ile ulus arasında ayrım yapmaktadır. Ona göre bazı Türkçüler de ulusu kavim topluluğuyla karıştırırlar. Kavim ile ulusal öz arasında bir ilişki olmadığını düşünen Gökalp, kavimsel saflık geçmiş tarihlerde kalmıştır. Yani kavim, millet fikrinin gelişmediği eski toplumlar için geçerlidir (Gökalp, 2010a:24-25). Oysa Ahmet Naim, kavme tam olarak Ziya Gökalp'ın millet kavramındaki anlamını vermektedir. Ayrıca Ahmet Naim'in kavim (1rk) ve millet (din) kavram karşıtlığına paralel bir şekilde, Ziya Gökalp, millet (ulus) ve ümmet (din) kavramlarını kullanmaktadır. $\mathrm{Bu}$ kavram seçiminde, Ahmet Naim'in geleneğin otoritesi etrafinda tartışmayı sürdürmek istemesine karşılık, Gökalp'in sosyolojik analize dayalı olarak geçmişte olanı, şimdiki zaman içinde yeniden üretmek isteği yatmaktadır. Gökalp'ın “yeni kavramlar, çağın konuşmasıdır” (2010b: 19-22) demesi tam olarak bu anlattıklarımızı özetlemektedir. Tartışmanın İslamı tarafındaki Mehmet Akif'in bu dönemdeki şiirlerinde kavim, kavmiyetçilik yerine fikr-i kavmiyeti kullanması, İslamcılar ile Türkçüler arasında yürütülen düşünsel tartışmaların, mevzi savaşı olarak kavramlar üzerinden yapıldığının önemli bir göstergesidir. Çünkü İslamcılar, yeni olanın hükmünü eski kavramlarla verdikleri sürece galip gelmekte olduklarının farkındadır. Yine de Ahmet Naim, Musa Kazım, Ahmet ve Nüzhet Sabit'in de kavmiyet tabirini kullanması, Osmanlı siyasal düşüncesinde kavramların yeni politik kültür tarafından yer değiştirmeye daha uğramadığını göstermektedir.

Ahmet Naim, Dar'ul Fünun'da ümmet ve millet konusunu Ziya Gökalp ile tartışırken, Gökalp'e 'ayet ve hadislerin manasını değiştirerek dinsiz' olduğunu söylemektedir (Hansu, 2007: 32). Gökalp bu tartışmadan bir yıl önce (1913) Türkleşmek, İslamlaşmak, Muasırlaşmak adlı kitaba temel olan makalelerini yayınlamaya başlamıştır. Bilindiği gibi Gökalp, bu makalelerinde İslam ile milliyetçiliği uzlaştırma çabası içindedir. "Dinsizlik" suçlaması, kavramları bağlamlarından koparmaya yönelik bir eylemi nitelemeye dönüktür.

Sonraki dönemlerde, milliyet kavramı, anlam değişmesine uğramasına rağmen tercihlerini hep korumuştur. Öğrencilerinden olan Macid Gökberk'in tanıklığına göre Ahmet Naim, "hep kavmiyet derdi, milliyet demezdi." Niyazi Berkes de "onun dilinde milliyetçilik, dincilik demekti” (Kara, 2005: 228-233) derler. Tartışma cumhuriyet döneminde c1lız bir şekilde devam etmiştir. Birinci Meclis'te Hamdullah Suphi'nin, Akif'e yönelik olarak "Kendileri milletperverliğin daima aleyhinde enfes şiirler yazmışlardır." sözüne karş1lık Akif'in, “Ben kavmiyet aleyhinde bir adamım, milliyet aleyhinde değil." (Düzdağ, 1997:176) diye cevap vermesi kavramların henüz siyasal olarak oturmadığını göstermektedir.

\subsection{Eleștirinin Sınırları}

Ahmet Naim, milliyetçileri dini esas alarak ikiye ayırmaktadır. Fakat milliyetçi düşünce kendi içinde dini esas alan bu sınıflandırmayı aşan farklı görüş ve düşüncelere sahiptir. Örneğin dine karşı saygılı olan Ziya Gökalp, Yusuf Akçura ve Ahmet Ağaoğlu arasındaki farkları göz ardı etmektedir. Georgeon'un (2009-89-93) Ziya Gökalp ile Akçura'yı karşılaştırdığı çalışmasında, iki düşünür arasında çok önemli farklar tespit etmektedir. Akçura'ya göre ulus, 1rk, dil ve ortak gelenekle tanımlanır. Gökalp'a göre ise "millet lisanca, dince, ahlakça, bediiyatça müşterek olan, yani aynı terbiyeyi almış fertlerden mürekkep bulunan zümredir." Ziya Gökalp'ın ümmetin türevi olan bir ulus inancına sadık kaldığ söylenebilir. Ziya Gökalp'ın pantürkist tezlerlerle arası iyi olmasına karşılık, özünde kararlı bir Osmanlıcı olarak kaldığı bilinmektedir; onun için ulusal topraklar Osmanlı Devleti'nin topraklarıdır. Akçura, Ziya Gökalp'i ittihad-1 anasır politikasına bağlılığından dolayı eleştirmektedir. Akçura, Türk toplumunun batılılaşmasını Abdullah Cevdet gibi ideolojik bir seçim olarak değil, pratik bir zorunluluğun sonucu olarak düşünmektedir. “'O, 'Avrupalılar'dan demiryolu köprüsü ve havada uçma makinesi yapmayl öğrenelim ama Avrupalıca düşünmek usulünü zinhar talim etmeyelim, mezhebine bir türlü aklım ermez' diyordu." Georgeon (2009: 4) Akçura, tarih ve antropolojinin gelişmesi ile birlikte Türk milliyetçiliğinin ikileminin derinleşmekte olduğunu düşünür. İkilem çözülmez bir şekle varlığını korumaktadır. Tarihsel kökler mi, bir coğrafyada kökleşme mi? Gökalp, Osmanlı coğrafyasında kökleşmeyi, Akçura ise tarihsel kökleşmeyi seçmekteydi. Gökalp'ın Osmanlı havzasında "Türkleşmeyi”" seçmesi ve "Esasları" bu coğrafyada 
araması, makalelerinin çoğunu yayınlattığı İslam Mecmuası'nı seçmesinde de kendini göstermektedir.

Ayrımın kendisinde sorun olduğu gibi resmin doğru çizildiğinden de şüphe etmek gerekir. Çünkü, Ziya Gökalp'ın düşüncelerini de tam temsil etmemektedir. Ziya Gökalp, İslamcılar tarafindan dile getirilen Hulagu'nun yaptıkları ile Türkçüler arasında kurulan irtibattan oldukça rahatsızdır. Ahmet Naim'e dolaylı olarak cevap verir. “Türkler'de milliyet hissi uyanmaya başlayınca Türk kelimesi başka türlü hücumlara maruz kaldl. Hülagu'nun vahşice zulümleriyle Türkçülük arasında bir münasebet varmış gibi, hücum hileleri yapıldı. Bir taraftan da Türkçülük İslamcılı̆̆a zıt olarak suçlanır. Hâlbuki Türkçülerin gayesi muasır bir İslam Türklüğ̈̈dür. Türkçülerin millet ülküleri Türklükse, ümmet ülküsü de Íslamlıktır." (Gökalp, 2010b: 41).

Ahmet Naim, milliyetçi projenin en azından o dönemde var olan tedrici düşüncesini dikkate almamaktadır. Ziya Gökalp, İslam birliğinin uzun bir zaman içinde belki gerçekleşebileceğini, fakat bu zamana kadar milletlerin milli uyanışlarını ve toplumsal bağımsızlıklarını sağlamaları gerektiğini savunmaktadır (Gökalp, 2010b: 75). O dönemde üzerinde durulan aile-i İslamiyye teorisine göre, İslam birliğine milliyetçi gelişmeleri tabi kılma eğilimleri sezilmektedir. Birlik iki safhada gerçekleşir. Birinci safhada, her İslam kavmi kendini milliyet alanında geliştirmeli, mümkün ise bağımsız bir devlet olarak kurulmalıdır. İkinci aşama ise kurulan bu devletler birleşmeli ve İslam birliği oluşturulmalıdır (Tunaya, 2003: 81).

Ahmet Naim'in, ittihadın milletlerle mi yoksa fertlerle mi sağlanacağ1 veya nasıl sağlanacağı ile ilgili görüşleri bulunmamaktadır. Ancak milli bilince karşı olmasından Ahmet Naim'in ittihadı fertler düzeyinde düşündüğü söylenebilir. Aile-i İslamiyye görüşünün temelinde yerel düzeyde milletlerin bağımsızlıklarını kazanmaları ve ekonomik ve kültürel gelişmelerini tamamlamaları bulunmaktadır. Aile-i İslamiyye, ittihadı geleceğe havale ederken, şimdi zamanda ise milliyetçiliği onun hazırlayıcısı olduğu için desteklemektedir. Bu açıdan Ahmet Naim için aile-i İslamiyyeyi savunmak ile rrkçılık arasında geçişli bir alan olduğunu söylemek zor olmayacaktır. Ziya Gökalp'te (2010b:41) bu düşünce “Türk kavmi 'ben varım' dedikten sonra mesuliyetini daha iyi değerlendiriyor... dindaş ve devletdaşlarlyla daha güzel anlaşmak yolların bulabiliyor." "Nefsini bilen rabbini bilir, kendini tanıyınca diğer kavimlerin haklarını da bilir...Türkçülerin ayrıca bir ümmet programları da olmall”. Ziya Gökalp, bu cümlesiyle Afgani'nin siyasal projesine benzer şeyleri ifade ederken Ahmet Naim'in görüşleri ile uzaklıklarını göstermektedir. Ahmet Naim, ittihad-1 İslam'a karşı olmakla temellendirdiği 1rkçılık görüşü nedeniyle, Ziya Gökalp (2010b: 42) tarafından, isim verilmeden "İslam milliyetçisi" olarak adlandırılmasını kolaylaştırmıştır. Fakat Ahmet Naim, (2018:118) bu konuda oldukça serttir. Çünkü "bir insan kendi kavmini sevmekle diğer Müslümanları niçin sevmesin' demeyiniz." Aileler arasında var olan tatsızlıkların büyük neticeler doğurması gibi Müslümanlar arasındaki tatsızlıklar da muhabbettin düşmanlığa tekabül etmesini sağlar, der. Bu sözleri ile Ziya Gökalp'ın Türkçülerin ümmet programları da olmalı ve İslam birliği sağlanıncaya kadar "Müslüman kavimler milli uyanışlar, milli uğraşmalardan yükselmeden, hiç olmazsa toplumsal bă̆ımsızlıklarını muhafazadan mahrum mu kalsınlar?" (Gökalp, 2010b: 76) şeklindeki sözlerine katılmamaktadır. Gökalp'in 'Türkleşmek, İslamlaşmak, Muasırlaşmak' düşüncelerine de aynı nedenle "çatal kazık" demektedir: "Halbuki Türk meselidir. Çatal kazık yere girmez" (Ahmet Naim, 2018:118).

\section{Eleştiriye Cevaplar: Ağaoğlu ve Gökalp}

Ahmet Naim'in 'Dava-yı Kavmiyet' makalesinden sonra, Ahmet Ağaoğlu, Türk Yurdu'nda bir cevap neşreder. Ziya Gökalp ise yazılarında dolaylı olarak cevap vermektedir. Ağaoğlu'nun makalesini iki bölüm üzerinden değerlendireceğiz. İlk bölümde, kendisine yöneltilen ve gerçek dişı olarak değerlendirdiği iddialara cevap vermektedir. Ona göre, milliyet akımıyla ilgili yazanlar, bu akımı okumak, anlamak amacıyla yazılı kaynakları değil, "deniliyor", “işitiliyor" gibi asılsız haberleri temel almaktadır. Ahmet Naim'in yazdığı şeyleri, herhangi bir gazete veya basılı bir metin aracılığıyla teyit edemediğini söylemektedir. Bununla birlikte Ağaoğlu, (1997: 582) İslamiyeti kendilerine dava edinmiş kişilerin Türkçülerin nazarında çok muhterem ve saygın kişiler olduklarını, bu nedenle onların milliyetçilerle ilgili görüşlerini tartışma ve düzeltmenin kendisi için bir vazife ve şeref telakki ettiğini düşünür. Ağaoğlu'nun bu düşüncesi, milliyetçi hareketlerin, İslam'1 halen meta-ideoloji olarak toplumu ve devleti kuran unsur olarak düşünmelerinin sonucudur. Ahmet Naim, ideolojik sınırları belirlemeye, içeride ve dışarıda olanları ifade etmeye çalışsa bile II. Meşrutiyet'te ideolojik bir akım haline gelen İslamcılığın ideolojik çerçevesinin net olarak daha çizilemediğini de göstermektedir. Çünkü Ahmet Naim tarafindan savunulan düşünceler halen ideoloji olarak değil, din dilinin içinde gelişen bir düşünce olarak Ağaoğlu tarafından anlaşılmaktadır. Ağaoğlu ilk bölümde temelde; (1997:581)

i. Ahmet Naim'in Halis ve Türk İslamcı ayrımının indi, keyfi ve gerçek dişı olduğunu bundan dolayı "Türkçülük gayr-i kabil-i taksim bir vahid-i küldür." düşüncesini savunmaktadır. (Türkçüler bölünemezler.)

ii. Ona göre İslam ve Türkçülük arasında sınır çekmek mümkün değildir. Türkçülük akımı, özellikle gençlerde İslamiyet'e olan bağlılığı artırmaktadır. (İslam ile Türkçüler arasında karşıtlık yoktur.)

iii. Ağaoğlu, toplumsal işlevinden dolayı, dinin toplumun temeli ve önemli unsuru olduğunu ileri sürmektedir. (Din olmadan millet olmaz.)

Ağaoğlu, (1997: 583-4) Ahmet Naim'in Türkçüleri ayırmasına itiraz etmektedir. Önemli olan itirazının gerekçesidir. Ona göre, Ahmet Naim'in vesikaya dayanmayan düşüncesi, Türkçüler arasında dinsizliği geliştiren kişilerin olduğuna dair varsayıma dayanmaktadır. Ağaoğlu, Türkçülük akımının içinde yer alan birisi olarak, aralarında değil dinsizliği yayan kişilere tesadüf edilmesi bunlara hoşgörü ile bakan milliyetçilerin dahi olmadığını savunur. Ağaoğlu, düşüncesini, dinin toplumsal yapıdaki işlevine dayanarak açıklamaktadır. Ona göre din, milletin, en mühim esası ve öğesini oluşturduğundan milliyetçilerin dinin bu rolünden dolayı ona uzak durmaları düşünülemez. Aşağıda görüleceği gibi 
Ağaoğlu, milleti, iki açıdan tanımlamaktadır: Dil ve din. Bundan dolayı, Türkçüler arasında Halis ve Türk-İslamcı gibi ayrımların olamayacağını savunur.

Ağaoğlu,(1997: 583-4) ikinci bölümde tarih ve sosyoloji etrafinda Ahmet Naim'in ayet ve hadislerin yorumuna itirazlarını dile getirir. Ona göre Ahmet Naim'in makalesinde üç temel iddia ileri sürülmektedir:

i. Dinsel açıdan: Milliyetçilik düşüncesine İslam'ın cevaz vermediği, onu yasakladığı gibi dinin ruhuna da aykırıdır.

ii. Devlet ve toplumsal açıdan: Milli akımlar zararlıdır.

iii. Meşruiyet açısından: Kaynağı Avrupa olduğu için bu akımlar doğal ve iç dinamiklerden yoksundur.

Ağaoğlu, bu bölümde İslam tarihini, milliyet, asabiyet ve kabile kavramlarının içeriklerini aydınlatmak amacıyla sosyolojik açıdan okumaya tabi tutar. Yöntemi, kutsal metinlerin literal yorumuna karşı yaşamın gerçekliğini ve vakayı yorumun sınırlarını koruma ve denetleme açısından esas almaktadır. Tamamlayıcı olarak sosyal gerçekliği, ayet ve hadislerin içeriğini inşa etme ve kasitlarını açıklamada kullanmaktadır. Kavramları, metnin tarih içinde yapmak istediği açısından içeriklendirmesi ve kavramı metnin dişında tarihsel olgu açısından inşa etmesi, Ağaoğlu'nun düşüncesine yetkinlik katmaktadır. Ahmet Naim'in metni esas alan literal yorumuna karşı, Ağaoğlu, metnin amacını açığa çıkaran tarihsel ve sosyolojik yaklaşımı önermektedir.

Ağaoğlu, tartışmayı, dinsel kavramların dışında vicdan-1 milli, vicdan-1 umumi, gaye-i müşterek, esasat-1 kavmiye, tabiat-1 eşya gibi yeni kavramlar kullanarak, tanımlar yaparak devam ettirir. Ağaoğlu, (1997: 583-585) İslam'ın millet hissini kabul etmediğine dair Ahmet Naim'in ne kadar malzeme var ise yığdığını düşünür. Oysa ileri sürdüğü kutsal metinlerde, "kavm" kelimesi geçmemektedir. Bu durumda, Ahmet Naim, asabiyet kavramı ile milliyet kavramını karıştırmaktadır. Fakat bununla birlikte, milliyet/kavmiyet kavramının içeriği konusunda ihtilafin olabileceğin kabul etmektedir. Ona göre milliyet "aynı surette hisseden bir kitle-i efrada" denilir. Müşterek hissiyatı oluşturan, inşa eden ve yayan, dil ve dindir. Dünyadaki bütün milletlerin gelenek, örf ve edebiyat gibi sanatsal unsurları dinden etkilenir. Dil, bu kültürün özeti ve öğesidir. Bu açıdan, milliyet kavramını asabiyet olarak değerlendirmek mümkün değildir. Ona göre asabiyet aile bireyleri ve ecdat arasındadır. Milliyet ise asabiyetten daha geniş olmakla birlikte bir mekânda bir araya gelemeyecek olan manevi bir kitleye bağlılığ1 ifade eder. Asabiyetin kendilik bilinci yoktur, oysa milliyet, kendilik bilincine ve vicdan-1 milliye sahiptir. Ahmet Naim'in ileri sürdüğü ayet ve hadisler, milliyeti değil, asabiyeti ortadan kaldırmayı amaçlamaktadır. İslam'ın emri Arap coğrafyasında birliği sağlamaktır. Böylece, Araplıkta, vicdan-1 umumi, gaye-i müşterek oluşturmaktır. Asabiyetten kurtulan Araplar, İslam'da birliği sağlamış oldular. Arapların vahdeti ve genel vicdanı oluşmadıç̧a İslamiyetin gelişmesi olanaksızdı. Ortak bir vicdan, ancak ortak bir gayeye sahip olabilirdi. $\mathrm{Bu}$ da milliyet düşüncesiyle sağlanabilirdi. Ağaoğlu, dini, müşterek vicdan ve gaye ile ilişkilendirdikten sonra Arap toplumunun gelişiminde dilin önemini, Kur'an-1 Kerim üzerinden açıklar. Kur'an Araplara ortak bir dil vermiştir. Dil sayesinde, milli birlik, millet vicdanının taşıdığ mefkûre ve gayeye hizmet eder. Böylece, Ağaoğlu, din ve dil üzerinden İslam'ın bir toplum oluşturduğunu düşünmektedir. $\mathrm{Bu}$ düşünce, politik açıdan ona geniş bir yorum sahası açacaktır.

Politik açıdan İslam tarihini değerlendiren Ağaoğlu, (1997: 586-90) Medine'de peygamber ve arkadaşlarının ortak his, fikir ve gaye yoluyla birlik oluşturmaya çalıştıklarını savunur. Ortak hissi, fikri ve gayeyi oluşturma açısından, farklı coğrafyalarda, çoklu din, dillere müsaade eden, hoşgörüsü ile tanınan İslam, Arap Yarımadası'nda İslam'ın dışında bir dinin yaşamasına müsaade etmemiştir. Böylece, Arap Yarımadası'nda İslam, Arap milletinin şiarı, vicdanı ve hissi olmaya çalışmıştır. Arapların vicdan1 millisi İslamiyettir. Ağaoğlu İslam'ın bu politikasına derin siyaset demektedir. Ona göre, Arabistan yarımadasında birliği sağladıktan sonra Beni Gassan ve Munzir gibi yarım ada dışındaki Arapları da İslam'ın içine dâhil ederek İslam, bütün Araplarda müşterek vicdan-1 milli oluşturmuştur. Kalplerin 1sındırılması ile ilgili ayeti de sadece Arap yarımadasında birliği sağlamaya dönük bir uygulama olarak değerlendirmektedir. Kendi vicdanını ve istikametini birlik aracılığıyla kuran Arap halkı için kabile içi asabiyet gibi düşünceler, milli vicdanın mefkûresi açısından aşıldığını söyler. Burada Ağaoğlu temel düşüncesine varmaktadır: İslam, milliyet esasını yıkarak değil, onu temin ederek, ona dayanarak yükselmiştir. Peygamber ve arkadaşları için temel uğraş, Arap milletinin birliğini sağlamaktı. Ağaoğlu tam da asabiyetin Arapları böldüğünü, birlik ve millet fikrinin ise bu sorunu aştığını düşünür. Evs/Hazreç, Ensar/Muhacir, Beni Sakife olayının, Ümeyye ve Haşim kavgalarının, Hz. Osman ve Hz. Ali dönemindeki karışıklıkların ve savaşların nedeni olarak asabiyeti ileri sürer. "Mefkûre vicdan-i milli ve gaye-i milli değişince onun yerine asabiyet hâkim olmaya devam etti. Islam'ın kaldırmak istediği de bu çatışmaya konu olan asabiyettir." (Ağaoğlu:1997:589-90).

Ağaoğlu'na göre (1997: 591-92) Kur'an'da insanların kavim olarak yaratıldığından bahsetmesinin amacı, kendi öz kimliklerini sağlayan dil ve kültüre müdahale edilmemesi gerekliliğini anlatmaktır. İslam, tabiat-1 eşyanın hilafina hareket etmeyeceğinden dolayı iman etmeyenlerin dahi din, dil ve adetlerine karışmak caiz değildir. İman edenler arasında ise iman ederek, ortak bir vicdan, manevi bir bağ ve din kardeşliği oluşur. Lisan, düşünme biçimi, hissiyat ve geçinme bir milletin kendine ait özel hususlardır. İslam, kişilere millet özelliği katan bu zati özelliklerinden vazgeçmeyi talep etmemiştir. Ağaoğlu, kavmiyetin zati özelliklerini belirleyerek dinin insan ve toplum doğasına muhalif bir şey söyleyemeyeceği inancıyla düşüncelerini destekler. Aynı zamanda, dil ile dilin inşa ettiği tefekkür arasında bağlantı kurmaktadır. (Türk tarz-1 tefekkür) Kavmiyeti böylece, dil üzerinden ortak bir düşünce ve hissiyat dünyası olarak tasvir etmektedir. Akçura'nın Osmanlıcılık düşüncesinde bütün unsurları kuşatacak ruh eksikliği olduğunu vurgulamasını hatırlarsak Türklüğün özel bir hissiyat (tarz-1 tahassüs) üzerinden de inşa edilmeye çalışıldığını görürüz.

Ağaoğlu, (1997: 592-4) Ahmet Naim'in İslam kardeşliğine kavmiyet fikir ve hissinin karşı olduğuna dair ikinci itirazı değerlendirir. Ağaoğlu, burada, ayet ve hadisin literal 
yorumuna karşı yaşamı ve vakayı koymaktadır. Ona göre, Ahmet Naim, "hayat ve vekayie müracaat" etme yerine, "hadislere ve rivayetlere, ayetlerin literal anlamlarına müracaat etmektedir.” İttihat, ittifak ve kardeşliğe ait hadis ve ayetleri zikrederek kavmiyetin yasak edildiğini savunmaktadır. $\mathrm{Bu}$ indi ve keyfi tefsirlerden hareket ederek Müslümanlar arasında eşitliği bozan zenginlik, âlimlik, geçimlilik gibi birçok durumu da yasaklamak gerekmektedir. Çünkü bunlar eşitliği bozduğu için hasede neden olmakta ve nifak çıkarmaktadır. Ayrıca Ağaoğlu, tarihe dayanarak Ahmet Naim'in kavmiyet akımının İslam kardeşliğini ve birliğini bozduğuna dair düşüncesini ispat etmek için bu akımlardan önce İslam dünyasında birliğin olduğunu göstermesi gerektiğini öne sürer. Kardeşliğe dayalı politik alanda birliğin çok sınırlı olduğunu söyleyen Ağaoğlu, örnek olarak herhangi bir Müslüman ne kadar "frenkperest" olsa bile Marakeş'in Fransızlar tarafindan istilasından üzüntü duyacağını ancak yine bu hissiyatın onu Marakeş'i savunmak için mücadele etmeye yöneltmeyeceğini söyler. Ağaoğlu, İslam kardeşliğinin eylem düzeyinde değil, hissiyat açısından geçerli olduğunu vurgular. İslam ülkelerinin birbirleri ile savaştığını da vurgulayan Ağaoğlu "Mefkûre, gaye emel başka şeydir, hayat başka. Hayatın mukteziyatı karşısında mefkûreler, emeller zebun kalıyorlar." der. Ağaoğlu, geçmişi böyle resmettikten sonra, kavmiyet akımının İslam kardeşliğini güçlendireceğine dair inancını ifade eder. Ona göre kavmiyet hissini oluşturan lisan ve dindir. Dünyadaki medeniyetleri de din açısından İslam, Hıristiyan ve BudaKonfiçyüs olarak üçe ayırmaktadır. Dil, ırk farklılığına rağmen medeniyetler arasında farklılığın din temelinden geliştiğini savunur. Herhangi bir Fransız kendisini dinsiz kabul etse bile iki bin yıllık Hıristiyan kültürü onun bütün hayatını kuşatır ve etkiler. Ağaoğlu, kavmiyet davasını güdenlerin bundan dolayı dini her zaman dikkate almak zorunda olduğunu söyler. Medeniyetin oluşmasında din, ne kadar etkili ve üretken olursa kavmiyet de bu oranda ondan istifade eder. Bundan hareket ederek Ağaoğlu şöyle der (1997: 595):

"İslamiyet Türkün dinidir, din-i millisidir, kavmisidir. Türk İslamiyeti cebren, mahkum ve mağlub olarak değil, hakim, galib olarak kabul etmiştir. Bin seneden beridir ki İslamiyetin en ağır yüklerini omzuna alarak taşımaktadır. İslam ve İslamiyet karşısında alnı açık başı yüksektir."

Türklerin İslamiyetten önceki yaşamlarından bahsetmelerini, Şamanizm'e ibadet ediyorlar, şeklinde vasıflandirılmasinı en menfur iftira olarak kabul etmektedir. Ona göre bir Türk "eskiye ricat" etmek istemez. Çünkü İslam medeniyet havzası içinde Türk kavimleri, lisan, hissiyat, geçim tarzları gibi kavmiyetin en temel esaslarını koruyabilmiş ve Türk kavminin birliği sağlanmıştır. Türklük hissi ve etkileri İslam medeniyeti havzasında korunabilmiştir. Ağaoğlu'na göre, "Türkler, Íslamiyeti bir din-i milli, bir din-i kavmi addediyorlar." (1997:594)

Ağaoğlu, (1997: 596) İslamiyetin Türklerin 'vicdan-i milli'si ve milletin esası olduğundan İslamiyetin yayılması ve gelişmesinin Türklerin en büyük gayesi olduğunu düşünür. İslamiyet ne kadar yükselir ve yayılırsa Türklüğün de o kadar yükseleceğini ve yayılacağını söyler. Ağaoğlu, bütün bunlardan, kavmiyetçiliği oluşturanın vicdan-i milli olduğunu onu da İslam'ın oluşturduğunu vurgulayarak "keşke" kavmiyetçilik daha önceden İslam halkları arasında yayılsaydı, her millet kendini tanısaydı, Arnavut bugünkü durumuna düşmezdi, demektedir. Ağaoğlu, kavmiyetçiliği bütün Müslüman halklarda etkili olması gereken bir akım olarak kabul etmektedir. Buna göre:

i. İslam ile kavmiyetçiliğin birbirini beslediğini düşünür. Çünkü İslam vicdan-ı milli oluşturmaktadır.

ii. Ağaoğlu, medeniyeti dinsel belirleme üzerinden yaptığı için, milletin gelenek ve göreneklerini oluşturan temel yap1 olarak dini görür. Bu nedenle Müslüman halkları aynı medeniyet içinde ele alır.

iii. Milliyetçiliği, Ahmet Naim'den farklı olarak ittifak ve ittihadın geliştireceği zemin olarak düşünür.

iv. Dil ve dini esas alan bir millet tanımını, milliyetçi cereyanların yoğun olduğu dönemde İslam birliğini oluşturma konusunda daha avantajlı görmektedir.

v. Ahmet Naim'in "Müslüman Türk, Kürt” tabiri yerine Müslüman tabirini yeterli görmesine karşılık, Ağaoğlu, "Müslüman Türk" olarak kimliği inşa etmeye çalışır. Bugünden bakıldığında, din ve etnik kimliğin bütünleşmesi, saf dinsel ve seküler olarak etnik yapının tanımlanmasından daha makul görülmektedir. (ì. Özel daha derin, şiirsel ve muhayyel bir tarzda kafir-mümin karşıtlığını temel alan farklı bir teşebbüste bulunmaktadir.)

vi. Ahmet Naim ile Ağaoğlu arasında kavmiyetten daha çok dinin kendisi ve toplumsal işlevi açısından değerlendirme farkı bulunmaktadır.

Her iki düşünür de kelimeler üzerinde zorlama yorumlarda bulunmuştur. Ağaoğlu'nun tartışmada İslamiyeti “milli din" "Türk'ün dini” olarak takdim etmesi, milliyetçilik hareketlerinde İslamiyetin belirleyici yönüne işaret etmektedir (Kara, 2005:294-295). Ağaoğlu'nun meseleyi sosyal bir vaka olarak ele alması, milliyetçiliğin sosyal faydalarını göz önüne almasına neden olmuştur. Böyle olunca Ağaoğlu'nun verdiği cevap da "Halka hizmet hakka hizmettir' şeklinde özetlenebilir (Akgün, Çalış ,2002:592).

Ziya Gökalp, Ahmet Naim'in eleştirilerine dolaylı olarak cevap vermiştir. Ahmet Naim'in asabiyet kavramını modern bir biçimde 'milliyetçilik' ile karşılamasına karşı çıkmıştır. "Íslamiyet asabiyeti, 'hakikate karşı boşuna harcanan emek' tabiriyle çirkin görmüş ve yasak etmiştir. Fakat bu asabiyet kendi yakınlarını tutma, şovenlikten gaye aşiret asabiyetidir ki, hala içimizde yürürlüktedir. 'Beni Kahtan' ile 'Beni Adnan' tabirleri de bu çirkin görme ve yasak etmenin aşiretlere ait olduğuna bir delildir." (Gökalp, 2010b: 75). Gökalp, hadisin milliyetçiliği değil, asabiyeti yasakladığını savunmaktadır.

\section{Sonuç}

İttihad-1 İslam düşüncesi, Osmanlı toprakları üzerinde yaşayan Müslüman halkların siyasi birliğini amaçlamaktaydı. Temel sorun, Osmanlı Devleti'nin varlığı içinde Müslümanların kendi varlıklarını nasıl sürdürecekleriyle ilgiliydi. 1870-1910 döneminde ittihad-1 İslam'la ifade edilebilecek İslamcılık, buna karşı olanlarda 
bile, meta-ideolojik bir politika olarak, tartıșmanın çerçevesini, sınırlarını ve dilini belirleyecek şekilde bütün kesimler tarafından kabul edilmişti. 1908-1914 döneminde bile Ahmet Ağaoğlu ve Ziya Gökalp, İslamciların eleştirilerine karşı kendi düşüncelerini dinsel bir alan içinde savunmaktadır. Ağaoğlu ve Gökalp, İslamcıların politikalarından daha çok, dinin milletin oluşumundaki rolü üzerinden tartışmayı sürdürmektedir. Bu bile, İslam'la ilgili tartışmanın meta-ideolojik bir alanda cereyan ettiğini göstermektedir. Etkinin birinci Dünya Savaşı boyunca sürdüğünü de söylemek mümkündür.

II. Meşruiyet döneminde İslamcılık ideolojik bir dile dönüşmeye başladığında, ideolojilerde var olan sınırları tayin eden "bizden değildir" dual tarzı etkili olmaya başladı. Vice versa. $\mathrm{Bu}$ dönemde, Ahmet Naim'in İslamcılığın politik sınırlarını çizerek İslamcılığın ideolojik bir özelliğe dönüşmesinde birçok yazar gibi katkısı olmuştur. Bu da onun istemediği sonuçlara neden olmuştur. Müslüman olduğunu söyleme ile İslamcı olmadığını söyleme, politik alanda sınırların keskin bir şekilde çizilmesiyle yaygın hale dönüştürülmüştür. Sünni geleneğin, esnek, kapsayıcı ve tartışma alanlarını azaltarak birliğe yönelik yaklaşımı, Osmanlı Devleti'nin bekasına dönük politik tutumları adına İslamcılık düşüncesi tarafından terk edilmiştir.

İslamcılığın milliyetçi tartışmalarda tarihsel ve teorik açıdan başarılı olduğunu söylemek hangi sonucu almayı düşündüğü açısından değerlendirilmelidir. İslamcıların milliyetçilik eleştirisi dinsel kavrama dayandığ 1 için (asabiyet vb.) sosyolojik niteliği baskın, modern milliyetçilik akımını açıklamada yetersiz olduğu söylenebilir. İttihad ve tefrika omurgası üzerinde oluşturulan, dinsel bütünlüğü amaçlayan dinsel dilin, kutsal metinlerin literal yorumlarından hareket etmesi doğal olmakla birlikte çağdaş kaygıları kapsama konusunda yeterli olduğunu söylemek mümkün değildir. Bununla birlikte, Ahmet Naim'in “yeni iman" “yeni bir tarih" "yeni kavim" icadı gibi kavramları, bugün etkili olan modern milliyetçi kuramlardan önce ifade etmesi, Osmanlı aydının entelektüel kavrayışının derinliklerini göstermektedir. Ahmet Naim, milliyetçiliğin yeni bir ulus inşa etme sürecini anlama konusunda anahtar kavramlar kullanmıştır. Ahmet Naim'in derin gözlemi burada aranmalidir.

Ahmet Naim'in savunduğu saf bir form şeklinde "Müslüman" kavramı yerine, "Müslüman Türk/Kürt/Arnavut/Arap" gibi canll, içerikli, kavramın tecessüsünü gösteren bir tanım, bugün daha doğru gözükmektedir. $\mathrm{Bu}$ strateji, Ağaoğlu'nun İslam'ın Türklerin milli dini olduğunu ileri sürmesindeki gibi Müslüman kavramı ile milliyet kavramını tarihsel momentte iç içe geçirdiği için ayrılmaz bir ikiliye dönüştürmektedir. Ağaoğlu'nun "Arnavut ayrılmazdı", itirazı bu nedenle yerindedir. Gökalp ve Ağaoğlu'nun II. Meşrutiyet dönemindeki yaklaşımları aile-i İslamiyye politikaları çerçevesinde daha reel gözükmektedir. Günümüzde, dinsel metinlerden daha ziyade süregelen tarihsel kimlik açısından millet ile din arasındaki aynılığı savunan Gaspıralı çizgisi, Kürt, Arnavut, Çerkez gibi her millet için geçerli olduğu koşulda, Ahmet Naim'in kaygısı olan milletlerin "dinsizleştirilmesine" karşı daha etkili olduğu söylenebilir. Kürt, Türk, Arap ve Arnavut kimliğinin müstakil olarak varlığını kabul edip onu İslam'la kuvvetlendirme çabası Müslüman halklar arasında uhuvveti besleyecektir. Ahmet Naim'in kabul etmediği Müslüman Türk, Kürt, Arap ve Arnavut tabirleri bu açıdan daha uygun bir stratejidir. Mücerred bir ümmetçilik yerine millet temelinde kardeşliğin ifade edilmesi yaşadığımız dönem için daha doğal ve doğrudur. Çünkü milletlerin İslam kimliği içinde erimesini beklemek ve talep etmek yaşamın gerçekliğinden kopmak anlamına gelmektedir. İnsanların kimlikleri, birçok unsur tarafından oluşturulduğundan saf İslami kimlik; saf Türk, Kürt, Arap ve Arnavut kimliği gibi mümkün değildir.

\section{Kaynakça}

Ağaoğlu, A. (1997). İslam'da Dava-yı Milliyet. İçinde: İ. Kara (Haz.) Türkiye'de İslamcılık Düşüncesi Metinler Kişiler, 3. Baskı, İstanbul: Kitabevi, s. 581-595.

Ahmet Naim, (2018a.). Arap İhvânımıza Bir Nasihatımız. İçinde: M. C. Kaya; İ. Kara (Ed.) Babanzâde Ahmet Naim Hayatı-Eserleri-Fikirleri (s.343-345), İstanbul: Zeytinburnu Belediyesi Kültür Yayınları.

Ahmet Naim, (2018b). Arap İttihâd Kulübü. İçinde: M. C. Kaya; İ. Kara (Ed.) Babanzâde Ahmet Naim Hayat-Eserleri-Fikirleri (s. 346-51) İstanbul: Zeytinburnu Belediyesi Kültür Yayınları.

Ahmet Naim, (2018c). İslâm'da Da'vâ-yı Kavmiyyet: Ta'kīb ve Tenfîz Mecmûası Sâhibi Nüzhet Sâbit Beyefendi'ye. Sebîlürreşâd,(Yay. Haz. İ.Türe), Cilt 12, Say1 293, İstanbul: Bağcrlar Belediyesi Kültür Yayınları Dizisi, s. 112-125.

Ahmet Naim. (2017). Hadîs-i Şerîf. Sebîlürreşâd, (Haz. İ. Türe) ).Cilt 9, Say. 212, (26 Eylül 1912) İstanbul: Bağcılar Belediyesi, Kültür Yayınları Dizisi s. 6567.

Akçam, T. (2002). Türk Ulusal Kimliği Üzerine Bazı Tezler. İçinde: T. Bora (Ed.) Modern Türkiye'de Siyasi DüşünceMilliyetçilik. Cilt 4, (s. 53-62) İstanbul: İletişim Yayınları.

Akçura, Y (1976). Üç Tarz-ı Siyaset, Ankara: Türk Tarih Kurumu Yayınları.

Akgün, B., \& Şaban H. Ç. (2002). Tanrı Dağı Kadar Türk, Hira Dağı Kadar Müslüman. İçinde: T. Bora (Ed.) Modern Türkiye'de Siyasi Düşünce Milliyetçilik. Cilt 4.(.584-600, İstanbul: İletişim Yayınları.

Ali Kemal (1976). Cevabımız. İçinde: $\ddot{U} c ̧$ Tarz-ı Siyaset (s, 37-44) Ankara: Türk Tarih Kurumu Basımevi.

Arai, M. (2008). Jön Türk Dönemi Türk Milliyetçiliği. Tansel Demirel (Çev.) İstanbul: İletişim Yayınları.

Balibar, E. \& Wallerstein I. (2007). Irk Ulus Sinıf,Belirsiz Kimlikler. Nazlı Ökten (Çev.) İstanbul: Metis Yayınlar1.

Bora, T. (2002). Sunuş. İçinde: T. Bora (Ed.) Modern Türkiye'de Siyasi Düşünce Milliyetçilik. Cilt 4 (s.15-22) İstanbul: İletişim Yayınları. 
Bora, T. (2009). Türk Sağının Üç Hali, İstanbul: Birikim Yayınlar1.

Çetinsaya, G. (2004). İslamcılıktaki Milliyetçilik. İçinde: T. Bora (Ed.) Modern Türkiye'de Siyasi Düşünce Milliyetçilik. Cilt 4 (s.420-422), İstanbul: İletişim Yayınları.

Çetinsaya, G. (2009). İslami Vatanseverlikten İslam Siyasetine.İçinde: M. Ö. Alkan (Ed.) Modern Türkiye'de Siyasi Düşünce Cumhuriyete Devreden Düşünce Mirası: Tanzimat ve Meşrutiyetin Birikimi Cilt 1 8. Bask1, (s. 265-272), İstanbul: İletişim Yay.

Düzdağ, M. E. (1997). İslam ve Irkçılık Meselesi. İzmir: Çağlayan BYD,

Georgeon, F. (2002). Türk Milliyetçiliği Üzerine Düşünceler: Suyu Arayan Adamı Yeniden Okumak. Modern Türkiye'de Siyasi Düşünce Milliyetçilik Cilt 4 (s. 23-28), İstanbul: İletişim Yayınları.

Georgeon, F. (2009). Osmanll-Türk Modernleşmesi (19901930). Ali Berktay (Çev.), İstanbul: Yapı Kredi Yayınlar1.

Gökalp, Z. (2010a). Türkçülüğün Esasları, İstanbul: Akvaryum Yayınevi.

Gökalp, Z. (2010b). Türkleşmek Islamlaşmak Muasrılaşmak, Ankara: Akçağ Yayınları.

Gündüz, M. (2007). II. Meşrutiyet'in Klasik Paradigmalar1, Ankara: Lotus Yayınları.

Hansu, H. (2007). Babanzade Ahmet Naim, İstanbul: Kaynak Yayınları.

Kara İ. (2009). İslâm Düşüncesinde Paradigma Değişimi. İçinde: M. Ö. Alkan (Ed.) Modern Türkiye'de Siyasi Düşünce Cumhuriyete Devreden Düşünce Mirası: Tanzimat ve Meşrutiyetin BirikimiCilt 18. Baskı, (s. 234-44) İstanbul: İletişim.

Kara, İ. (1997). Türkiye'de İslamcılık Düşüncesi Metinler Kişiler, 3 Baskı, İstanbul: Kitabevi.

Kara, İ. (2005). Din ile Modernleşme Arasında Türk Düşüncesinin Meseleleri. İstanbul: Dergah Yayınları.
Kara, İ., (2018). İslâm'da Dava-y1 Kavmiyet'in Esas Meselesi Ne İdi? İçinde: M. C. Kaya; İ. Kara (Ed.)Babanzâde Ahmet Naim Hayatı Eserleri Fikirleri,(191-218) İstanbul: Zeytinburnu Belediyesi Kültür Yayınları.

Kushner, D. (2009). Türk Milliyetçiliğinin Doğuşu 1876 1908, Ş.S. Türet; R.Ertem; F. Erdem (Çev.) İstanbul: Kesit Yayınları.

Manastırlı İsmâil Hakkı (2012). Mevâ'iz. Sırâtımüstakīm (Yay. Haz. İ.Türe), Cilt 1 Say. 2 (3 Eylül 1908) İstanbul: Bağcılar Belediyesi, Kültür Yayınları Dizisi İstanbul. s. 27.

Mardin, Şerif (2010). Jön Türklerin Siyasi Fikirleri, İstanbul: İletişim Yayınları.

Mehmet Akif (2017). Hutbe ve Mevâ1z. Sebîlürreşâd, (Haz. İ. Türe) Cilt 9, Say. 212, ( 6 Şubat 1913) İstanbul: Bağcılar Belediyesi, Kültür Yayınları Dizisi s. 369-372.

Ozon M. N. (1997). Namık Kemal ve Ibret Gazetesi. İstanbul: YKY.

Said Nursî (2004). Münazarat, İçinde: İçtimâ̂ Dersler, (s.77-150), İstanbul: Zehra Yayıncılık,

Sevil H. K. (2005). Ittihat ve Terakki Döneminde Íslamcllik Hareketi (1908-1914).Doktora Tezi. Ankara Üniversitesi Sosyal Bilimler Enstitüsü Tarih (Yakınçağ) Anabilim Dalı.

Somel S. A. (2009). Osmanlı Reform Çağında Osmanlıc1lık Düşüncesi (1839-1913) İçinde: M. Ö. Alkan, Modern Türkiye'de Siyasi Düşünce Cumhuriyete Devreden Düşünce Mirast: Tanzimat ve Meşrutiyetin BirikimiCilt 1 8. Baskı, s.88-97, İstanbul: İletişim Yayınları.

Sosyal, A. G. (1986). Ahmet Ăgaoğlu (1869-1939) The Life anda Thought of a Turkish Nationalist During 1908-1918. Doktora Tezi: Boğaziçi Üniversitesi.

Tunaya, T. Z. (2003). İslamcılık Akımı. İstanbul: İstanbul Bilgi Üniversitesi Yayınları. 